\title{
Assessment of physico-chemical parameters and trace heavy metal elements from different sources of water in and around institutional campus of Lumami, Nagaland University, India
}

\author{
Maqbul Hussain ${ }^{1}$ - Latonglila Jamir ${ }^{1}$ - Maibam Romeo Singh ${ }^{2}$
}

Received: 9 July 2018 / Accepted: 29 March 2021 / Published online: 11 April 2021

(C) The Author(s) 2021

\begin{abstract}
The main emphasis of this study was to assess the status of drinking water quality from four different water sources available in and around an institutional campus of Lumami, Nagaland University, with special reference to the detection of trace heavy metal elements. The results of the physico-chemical parameters of the water show that values of $\mathrm{DO}, \mathrm{BOD}_{5}$ and free $\mathrm{CO}_{2}$ at S3 are beyond the permissible limit set by WHO and BIS. The values of DO in all the three stations (S1, S2 and S4) are near the maximum permissible limit of drinking water, indicating the deterioration of water quality, whereas the rests of the parameters are below the permissible limit of WHO and BIS. The detection of $\mathrm{Hg}$ in all stations along with alarmingly high concentrations of $\mathrm{Fe}$ and others such as $\mathrm{Cu}, \mathrm{Zn}, \mathrm{Mn}$ and $\mathrm{Se}$ is perceived as a matter of concern. On the other hand, $\mathrm{As}$ and $\mathrm{Pb}$ were not detected in any station. The detection of $\mathrm{Hg}$ and $\mathrm{Fe}$ in all the four types of water sources is an indication of contaminant hazards and needs drinking water treatment practices in these areas which in turn have implications on human health.
\end{abstract}

Keywords Physico-chemical parameters $\cdot$ Trace elements $\cdot$ Heavy metals $\cdot$ WHO $\cdot$ BIS $\cdot$ Permissible limit

\section{Introduction}

Natural water scarcity combined with the lack of access to safe drinking water and inadequate sanitation services is common problem associated with developing countries including India (WHO 2006). Toxic water contaminants such as heavy metals and carcinogens remain of primary concern due to their ability to cause adverse health effects after prolonged periods of exposure (DEWO 1989). Water contaminants are primarily sourced from geological conditions, industrial and agricultural activities, and water pollutants are further categorized as microorganisms, inorganic, organic, radionuclides and disinfectants (Nollet 2000). The contamination of potentially toxic elements (PTEs) released

Maibam Romeo Singh

romeomaibam@gmail.com

Latonglila Jamir

latongli.jamir@gmail.com

1 Department of Environmental Science, Nagaland University, Lumami 798627, India

2 Department of Botany, Centre for Biodiversity, Nagaland University, Lumami 798627, India from both natural (weathering and erosion of bedrocks and ore deposits) and anthropogenic (mining, agricultural and industrial) activities (Antoniadis et al. 2017a; Shah et al 2012) and finally contaminates the various water sources (Khan et al 2018; Tripathee et al 2016) that is nowadays a major environmental issue globally because of their highly toxicity behavior. PTEs such as iron ( $\mathrm{Fe})$, zinc $(\mathrm{Zn})$, copper $(\mathrm{Cu})$ and manganese $(\mathrm{Mn})$ are essential elements and required for normal human body functions. However, the excess of it is dangerous to health if exceeded beyond their threshold limits (Ullah et al 2017). Rest of the PTEs like lead $(\mathrm{Pb})$, cadmium $(\mathrm{Cd})$, nickel $(\mathrm{Ni})$, cobalt $(\mathrm{Co})$, arsenic (As) and mercury $(\mathrm{Hg})$ are extremely hazardous if present in trace concentration (Shakoor et al 2017; Saddique et al 2018).

Nagaland is located along the northeast corner of India extending between $25^{\circ} 6^{\prime} \mathrm{N}$ to $27^{\circ} 4^{\prime} \mathrm{N}$ latitude and $93^{0} 20^{\prime} \mathrm{E}$ to $95^{\circ} 15^{\prime} \mathrm{E}$ longitude covering a total geographical area of $16,579 \mathrm{sq} \mathrm{km}$. The state enjoys sub-tropical to warm temperate monsoonic types of climate with an annual mean rainfall of approximately $2600 \mathrm{~mm}$. In rural regions, where wellmanaged water transportation system and related infrastructures are not available, spring, streams and well water serve as chief source of drinking water. The main water sources of water in Nagaland are rivers and streams, which depend 
heavily on the amount of annual rainfall. Lumami campus of Nagaland University is situated in the rural and backward region of Nagaland in Zunheboto district. Pollution in river by way of using explosive for fish hunting, rock quarrying, sand mining, shifting cultivation practices, alteration of freshwater flows, road construction, soil erosion in agriculture and hilly areas, deforestation and dam building is prevalent in the state which finally leads to deterioration of freshwater ecosystems. Peoples living in and around the campus of the University heavily depend on tap water which source is mainly from the river and streams. Spring and well water available in and around the institutional campus come in need during shortage supply of tap water during winter. No information is available about the scientific studies of drinking water quality and potential sources of contaminations for all these water sources. The main hypothesis of this study is to test the extent of pollution level in the water quality so as we can check whether the water is suitable for domestic purposes. The study area being in the headquarter of Nagaland University, is therefore highly crucial to evaluate the drinking water quality status from different sources of water bodies available in the area in order to assure safe drinking water of its residents. Hence, we envisaged the evaluation of drinking water quality from different sources like tap, spring, well and stream water available in and around the institutional campus of Nagaland University, Lumami, with an objectives of determining the various physico-chemical properties of water from different sources and to compare the values obtained with the permissible limit of drinking water quality given by Bureau of Indian standard (BIS 1991) and WHO (2004). Also the study aims to detect the contaminants of PTEs and other trace heavy metal elements in the water samples.

This study will help in identifying some of the important parameters of physico-chemical variables which shows good indices of water quality. Different sources of pollution and heavy metals analyzed from the study may help in tackling the problems of pollution by way of awareness to the public for stopping them from further creation of such types of pollution. Recommendation measures and management program can be taken up by the people residing in the area. The results obtained will help the public precautious about the water they use for domestic purpose by way of water treatment, thereby improving the quality of human health. Implementation of improved management strategies of these water sources can be taken up. Further, data generated from the study will be useful by media, institutions, academicians, water treatment plants, municipality and the policy decision makers.

\section{Materials and methods}

\section{Description of the sampling stations}

Surface water samples for the analysis were collected from 4 sampling stations in and around the institutional campus of Nagaland University, Lumami, India. The four sampling stations selected were: Station 1 (S1): stream, station 2 (S2): tap water, station 3 (S3): well water and station 4 (S4): natural spring. The description and geographical coordinates of each sampling stations are described in Table 1. Location map of the sampling stations is shown in Fig. 1.

\section{Water sampling and analytical methods}

\section{Analysis of physico-chemical parameters of water}

From each sampling station, three water samples were collected monthly from September 2017 to April 2018 during morning hours of 9 a.m to $10 \mathrm{a} . \mathrm{m}$ in polyethylene plastic bottles rinsed three times with deionized water. Analysis could not be carried out for the month of January as the University was closed for winter vacation. Water temperature was measured on the spot using water thermometer. $\mathrm{pH}$ was measured with pen-type digital $\mathrm{pH}$ meter. $\mathrm{DO}$ was analyzed by Winkler's titrimetric method. BOD was estimated by Winkler's titrimetric method after 5-day incubation at $20^{\circ} \mathrm{C}$ followed by subtracting the values of titration from the initial and final DO. Free $\mathrm{CO}_{2}$ was determined by titrating $100 \mathrm{ml}$ of the water sample against $0.05 \mathrm{~N} \mathrm{NaOH}$ solution and using phenolphthalein indicator. Estimation of chloride was done by argentometric method by titrating the samples against $0.2 \mathrm{~N} \mathrm{AgNO}_{3}$ solution using $\mathrm{K}_{2} \mathrm{Cr}_{2} \mathrm{O}_{4}$ (potassium
Table 1 The description and geographical coordinates of each sampling stations

\begin{tabular}{|c|c|c|c|}
\hline Sampling station & Latitude & Longitude & Elevation \\
\hline $\begin{array}{l}\text { Station (S1): stream water (near } \\
\text { Threzaruku boys hostel) }\end{array}$ & $\mathrm{N} 26^{0} 13^{\prime} 30.25^{\prime \prime}$ & E $094^{0} 28^{\prime} 37.97^{\prime \prime}$ & $903 \mathrm{~m}$ above $\mathrm{ms}$ \\
\hline $\begin{array}{l}\text { Station (S2): tap water (Threzaruku } \\
\text { boys hostel, Lumami Campus) }\end{array}$ & $\mathrm{N} 26^{0} 13^{\prime} 31.19^{\prime \prime}$ & E $094^{0} 28^{\prime} 38.42^{\prime \prime}$ & $915 \mathrm{~m}$ above $\mathrm{ms}$ \\
\hline $\begin{array}{l}\text { Station (S3): well water (Chumpo boys } \\
\text { hostel, Lumami Campus) }\end{array}$ & N 26 $6^{0} 13^{\prime} 33.37^{\prime \prime}$ & E $094^{0} 28^{\prime} 36.13^{\prime \prime}$ & $949 \mathrm{~m}$ above $\mathrm{ms}$ \\
\hline $\begin{array}{l}\text { Station (S4): spring water (Iliki } \\
\text { Ladies hostel, Lumami Campus) }\end{array}$ & $\mathrm{N} 26^{0} 13^{\prime} 32.30^{\prime \prime}$ & E $094^{0} 28^{\prime} 38.19^{\prime \prime}$ & $860 \mathrm{~m}$ above $\mathrm{ms}$ \\
\hline
\end{tabular}



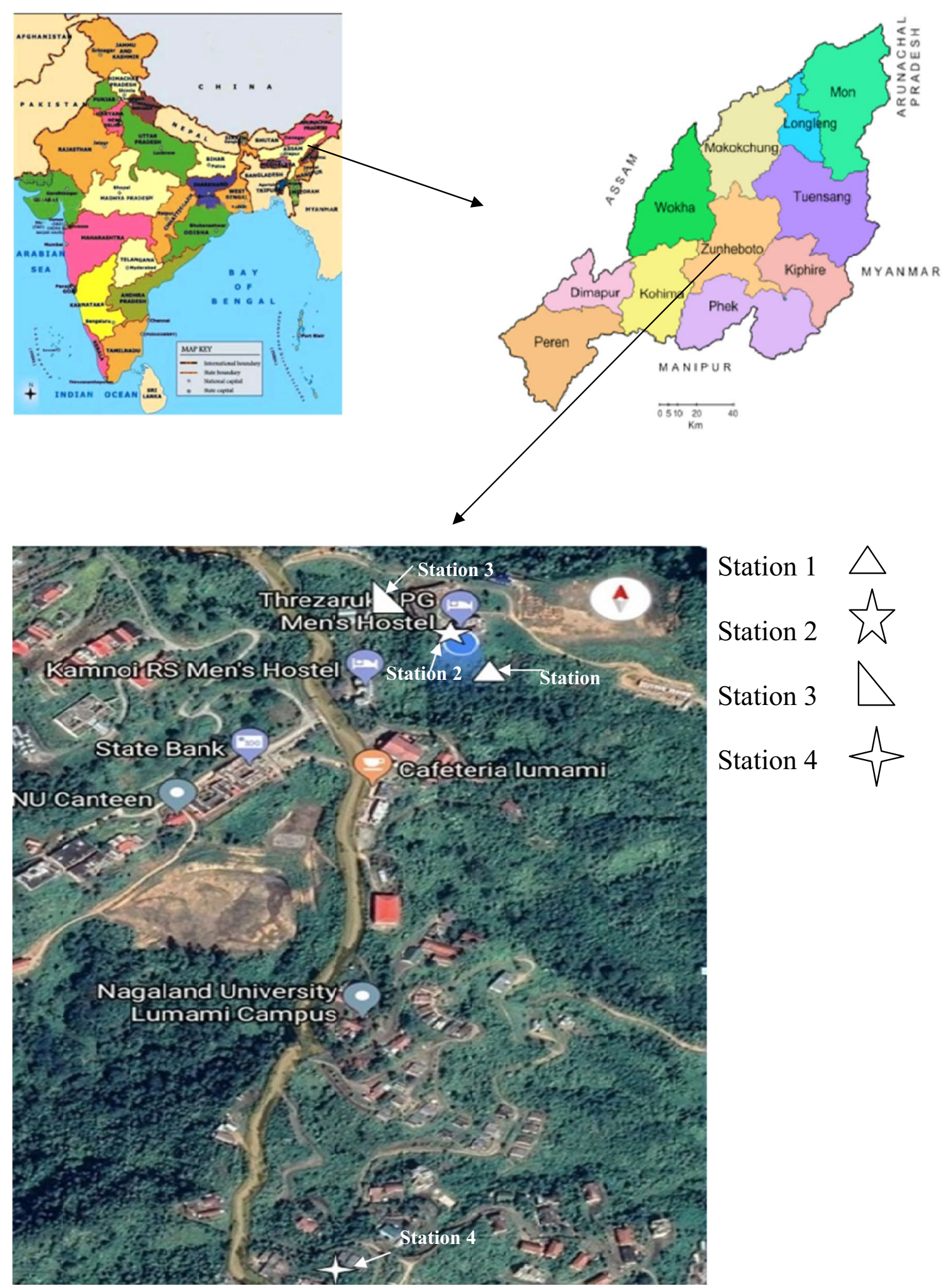

Fig. 1 Map showing the 4 (four) sampling stations 
chromate) as indicator. Total alkalinity was analyzed by titrating $100 \mathrm{ml}$ of water samples against $0.02 \mathrm{~N}$ conc. $\mathrm{H}_{2} \mathrm{SO}_{4}$ using methyl orange and phenolphthalein as indicator. Total hardness, calcium and magnesium hardness were determined titrimetrically by EDTA method using ammonia buffer solution and Eriochrome black-T as indicator. All the analysis were done in triplicates following standard methods prescribed by Trivedy et al. (1984); APHA (2005).

\section{Trace Heavy metal elements analysis}

Three water samples of each location were collected in polyethylene bottles that were pre-washed with laboratory detergent and rinsed with deionized water. The samples were treated with $1.5 \mathrm{ml}$ of nitric acid and stored at $4{ }^{\circ} \mathrm{C}$ until analysis was done. The total metal concentration of arsenic, lead, cadmium, copper, iron, manganese, mercury, selenium and zinc in the filtered and digestive samples is determined in $\mathrm{mg} / \mathrm{l}$ by using Atomic Absorption Spectrophotometer (AAnalyst 600 model, Perkin Elmer Inc., MA, USA). The AAS was calibrated with relevant grade standards.

\section{Statistical analysis}

The entire data set was computed for correlation matrix using SPSS (version 21.00). In order to evaluate the relationships between water quality parameters, Pearson's correlation matrix was executed for 11 parameters in 4 sampling station for three different seasons (summer, rainy and winter) with $p<0.5$ and 0.01 level of significance.

\section{Results and discussion}

\section{Physico-chemical parameters of water}

\section{Water temperature}

Temperature, the measure of intensity of heat stored in a volume of water, is highly correlated with atmospheric temperature and the morphometric features. Distribution of plankton and the other organisms depend largely on surface water temperature (Chandrahas 2001) as it regulates various physico-chemical and biological activities (Raney et al. 1969). As observed from the present study, average surface water temperature from the four stations ranges from 16.01 to $18.85^{\circ} \mathrm{C}$ (Table 2). Minimum temperature of $11^{\circ} \mathrm{C}$ was observed during Dec 2017 at S4 and maximum of $23{ }^{\circ} \mathrm{C}$ in March 2018 at S2 (Fig. 2a). Seasonally, the values of temperature were highest during rainy season $\left(20.1^{\circ} \mathrm{C}\right)$ followed by summer $\left(19^{\circ} \mathrm{C}\right)$ and winter $\left(15.33^{\circ} \mathrm{C}\right)$ as shown in Fig. 2b. In general, atmospheric and water temperature depend on geographical location and meteorological conditions such as rainfall, humidity, cloud cover, wind velocity, incoming solar radiation, humidity, altitude.

\section{$\mathrm{pH}$}

$\mathrm{pH}$ is a valuable parameter which guides not only the status of acid-alkali balance of the water but also serves as an important index of the degree of pollution. The factors like respiratory activity, exposure to air, temperature and

Table 2 Average physico-chemical properties of water quality in the four stations

\begin{tabular}{|c|c|c|c|c|c|c|c|}
\hline Parameters & S1 & S2 & & S4 & Range & $\begin{array}{l}\text { BIS } \\
(1991)\end{array}$ & $\begin{array}{l}\text { WHO } \\
(1983)\end{array}$ \\
\hline $\mathrm{DO}(\mathrm{mg} / \mathrm{l})$ & $3.64 \pm 0.36$ & $3.99 \pm 0.45$ & $2.93 \pm 0.26$ & $3.30 \pm 0.32$ & $2.93 \pm 0.26-3.99 \pm 0.45$ & $4-6$ & $4-6$ \\
\hline $\mathrm{BOD}_{5}(\mathrm{mg} / \mathrm{l})$ & $2.70 \pm 0.22$ & $3.55 \pm 0.16$ & $1.52 \pm 0.13$ & $3.00 \pm 0.29$ & $\begin{array}{c}1.52 \pm 0.13 \\
-3.55 \pm 0.16\end{array}$ & 3 & 2 \\
\hline Free $\mathrm{CO}_{2}(\mathrm{mg} / \mathrm{l})$ & $19.17 \pm 0.86$ & $20.11 \pm 1.00$ & $62.70 \pm 5.05$ & $25.77 \pm 1.47$ & $\begin{array}{l}19.17 \pm 0.86 \\
- \\
62.70 \pm 5.05\end{array}$ & NA & 22 \\
\hline $\mathrm{pH}$ & $7.01 \pm 0.08$ & $7.26 \pm 0.10$ & $6.64 \pm 0.11$ & $6.89 \pm 0.14$ & $6.64 \pm 0.11-7.26 \pm 0.10$ & $6.5-8.5$ & $6.5-8.5$ \\
\hline Chloride (mg/l) & $35.29 \pm 2.32$ & $35.29 \pm 1.57$ & $38.34 \pm 2.75$ & $32.25 \pm 1.86$ & $\begin{array}{l}32.25 \pm 1.86- \\
38.34 \pm 2.75\end{array}$ & 250 & 250 \\
\hline Total alkalinity $(\mathrm{mg} / \mathrm{l})$ & $21.57 \pm 1.24$ & $18.32 \pm 0.45$ & $24.57 \pm 1.28$ & $30.28 \pm 0.44$ & $18.32 \pm 0.45-30.28 \pm 0.44$ & 200 & 75 \\
\hline Water temperature $\left({ }^{\circ} \mathrm{C}\right)$ & $16.01 \pm 0.43$ & $18.32 \pm 0.45$ & $18.85 \pm 0.09$ & $16.87 \pm 0.51$ & $16.01 \pm 0.43-18.85 \pm 0.09$ & NA & NA \\
\hline Conductivity $(\mu \mathrm{S} / \mathrm{cm})$ & $91.41 \pm 5.02$ & \multicolumn{2}{|c|}{$110.18 \pm 4.33115 \pm 12.29$} & $96.80 \pm 11.05$ & $91.41 \pm 5.02-115 \pm 12.29$ & 300 & \\
\hline Total hardness (mg/l) & $59.71 \pm 4.53$ & $106 \pm 4.31$ & $138.57 \pm 17.02$ & $54.85 \pm 1.18$ & $\begin{array}{l}54.85 \pm 1.18 \\
-138.57 \pm 17.02\end{array}$ & 200 & \\
\hline $\mathrm{Ca}$ hardness as $\mathrm{CaCO}_{3}(\mathrm{mg} / \mathrm{l})$ & $22.50 \pm 1.56$ & $46.20 \pm 2.47$ & $64.80 \pm 7.672$ & $21.90 \pm 1.35$ & $\begin{array}{l}21.90 \pm 1.35 \\
- \\
64.80 \pm 7.67\end{array}$ & & \\
\hline $\operatorname{Mg}$ hardness(mg/l) & $7.84 \pm 0.99$ & $7.95 \pm 0.72$ & $9.76 \pm 1.47$ & $7.05 \pm 0.62$ & $7.05 \pm 0.62-9.76 \pm 1.47$ & & \\
\hline
\end{tabular}


Fig. 2 a Monthly variation in water temperature from the 4 sampling stations. b Seasonal variation in water temperature from the 4 sampling stations

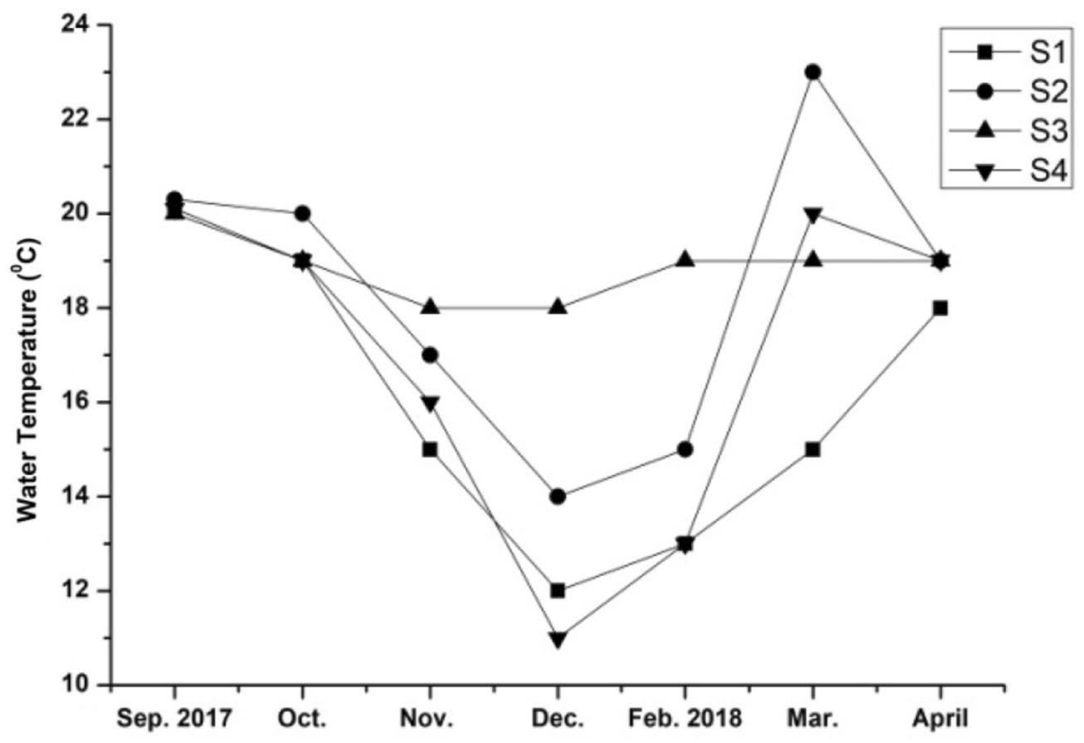

(a) Monthly variation in water temperature at 4 stations

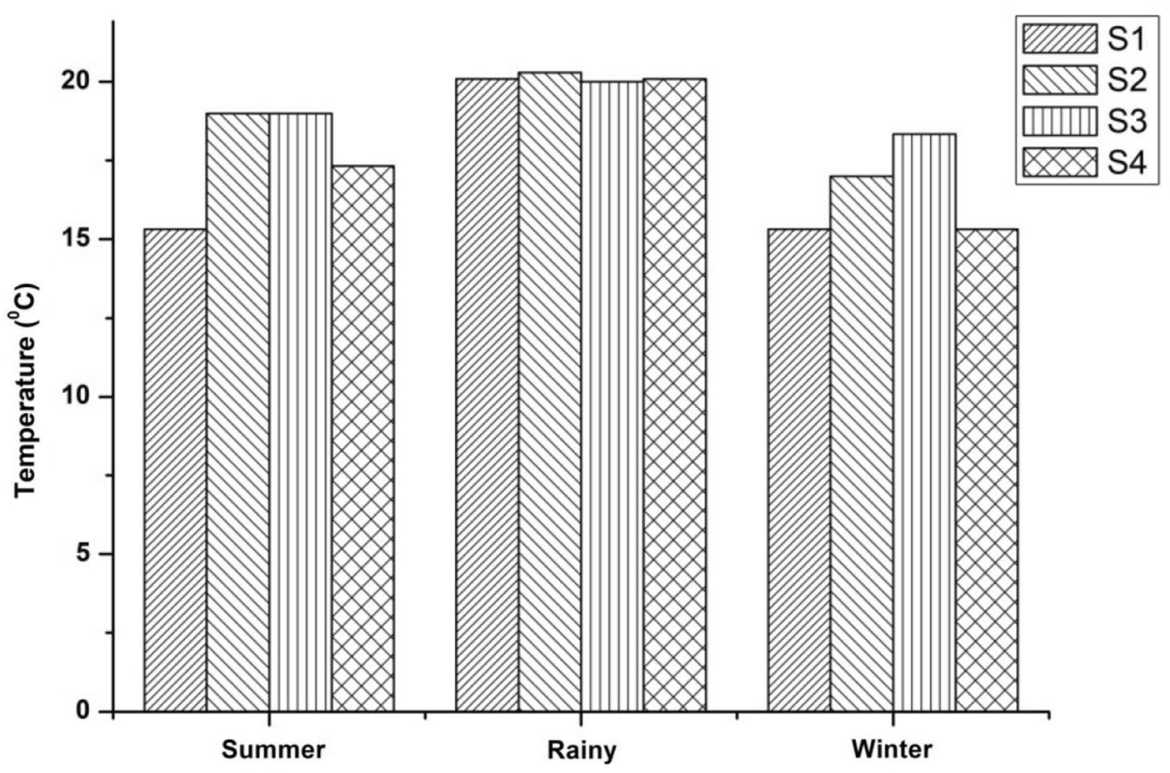

(b) Seasonal variation in water temperature at 4 stations disadvantages of sewage, etc., bring about the changes in $\mathrm{pH}$ (Saxena 1987). Minimum pH of 4.7 was exhibited at S4 in April 2018 and a maximum of 7.8 at S2 in Nov 2017 (Fig. 3a). Seasonally, the values of $\mathrm{pH}$ were low during summer at S4 (6.39) and high during winter at S2 (7.60) as shown in Fig. 3b. In this study, the concentration of average $\mathrm{pH}$ ranges from 6.64 to 7.26 and all the water samples analyzed have concentration within the safe limit of 6.5 to 8.5 standard set by the BIS and WHO (Table 2). Low pH during summer may be due to the formation of carbonic acid with the release of more free carbon dioxide due to microbial respiration at high temperature and increase decomposition rate from the organic waste deposited.

\section{Free $\mathrm{CO}_{2}$}

Free $\mathrm{CO}_{2}$ is the normal component of all natural water. Biological oxidation of organic matter and dissolved $\mathrm{CO}_{2}$ from air increases the level of $\mathrm{CO}_{2}$ in water (Rajput et al. 2004). Free $\mathrm{CO}_{2}$ in water is mainly originated from the respiration of aquatic biota, decomposition of organic matter and infiltration through the soil. Minimum free $\mathrm{CO}_{2}$ of $11 \mathrm{mg} / \mathrm{l}$ 
Fig. 3 a Monthly variation in $\mathrm{pH}$ from the 4 sampling stations. b Seasonal variation in $\mathrm{pH}$ from the 4 sampling stations

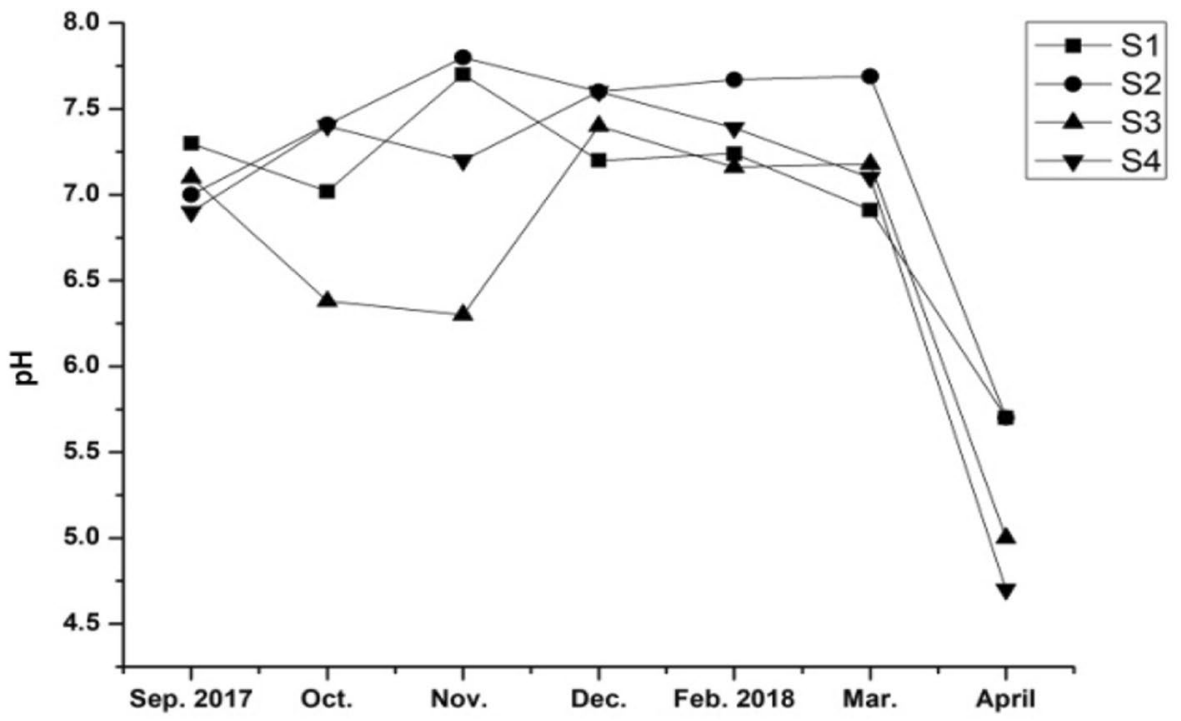

(a) Monthly variation in $\mathrm{pH}_{\mathrm{H}}$ at 4 stations

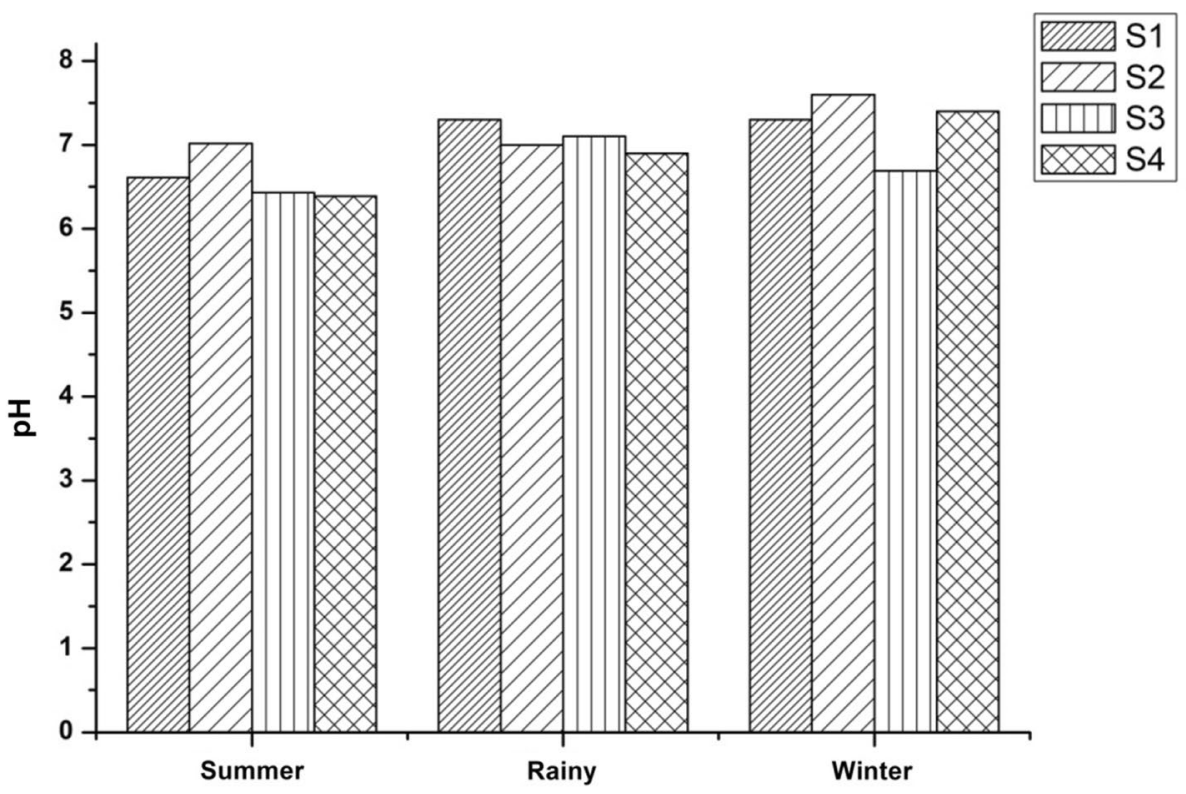

(b) Seasonal variation in $\mathrm{pH}_{\text {at }} 4$ stations

was recorded at S1 during November 2017 and maximum of $103.4 \mathrm{mg} / \mathrm{l}$ at S3 during November 2017 (Fig. 4a). Average free $\mathrm{CO}_{2}$ ranged from 19.17 to $62.70 \mathrm{mg} / \mathrm{l}$. Seasonally the values of free $\mathrm{CO}_{2}$ was lowest during rainy season at S2 (11 mg/l) and highest in winter at S3 (103.40 mg/l) as depicted in Fig. 4b. Free carbon dioxide is beyond the permissible limit given by WHO and BIS at S3 in well water (Table 3). Maximum value of free $\mathrm{CO}_{2}$ at $\mathrm{S} 3$ in well water in winter may be due to microbial activity and respiration of micro-organisms. It imparts acidity to water because of the formation of carbonic acid. High levels of carbon dioxide in well water indicate the presence of dead material undergoing decomposition.

\section{Dissolved Oxygen}

Dissolved oxygen (DO) is one of the most important parameter in the study of aquatic environment in view of its important participation in many chemical and biological reactions, and it plays a vital role in supporting aquatic life and very much susceptible to environmental changes. It is of prime important factor in natural water both as regular of metabolic process of biotic community and indicator of aquatic health. Dissolved oxygen content of any water body depends on the mixing and aeration of water, water temperature, duration of sunlight received and altitude of the area (Lamare and Singh 2014 and 
Fig. 4 a Monthly variation in free $\mathrm{CO}_{2}$ from the 4 sampling stations. b Seasonal variation in free $\mathrm{CO}_{2}$ from the 4 sampling stations

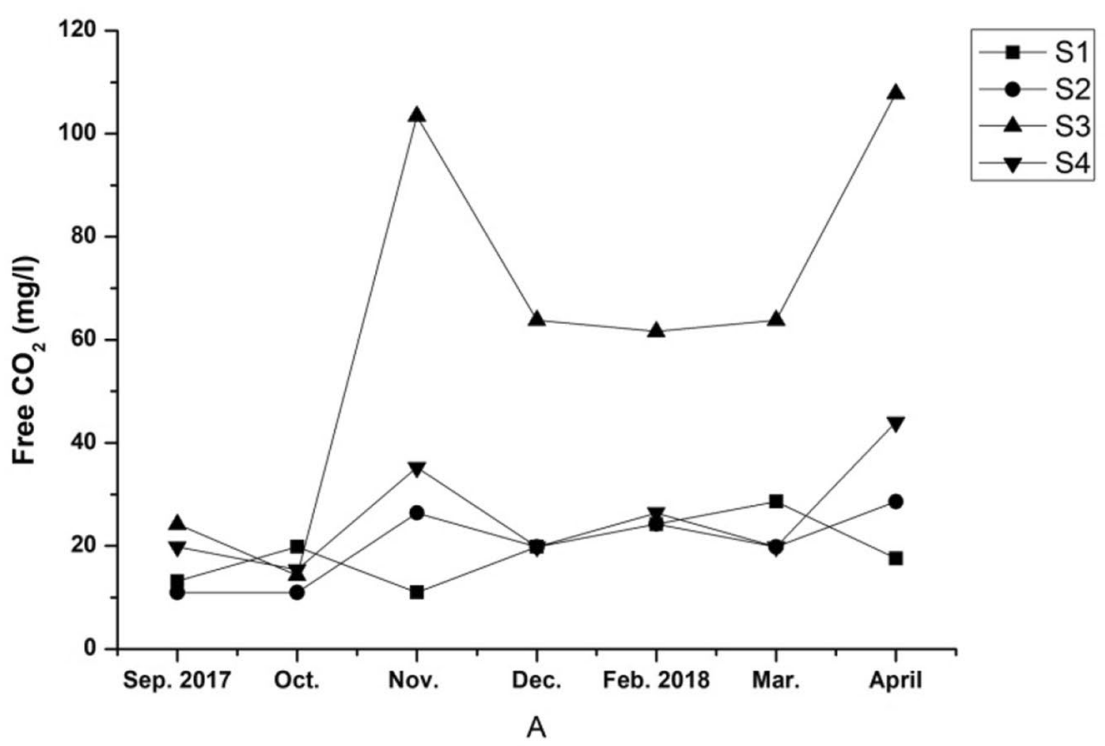

(a) Monthly variation in Free $\mathrm{CO}_{2}$ at 4 stations

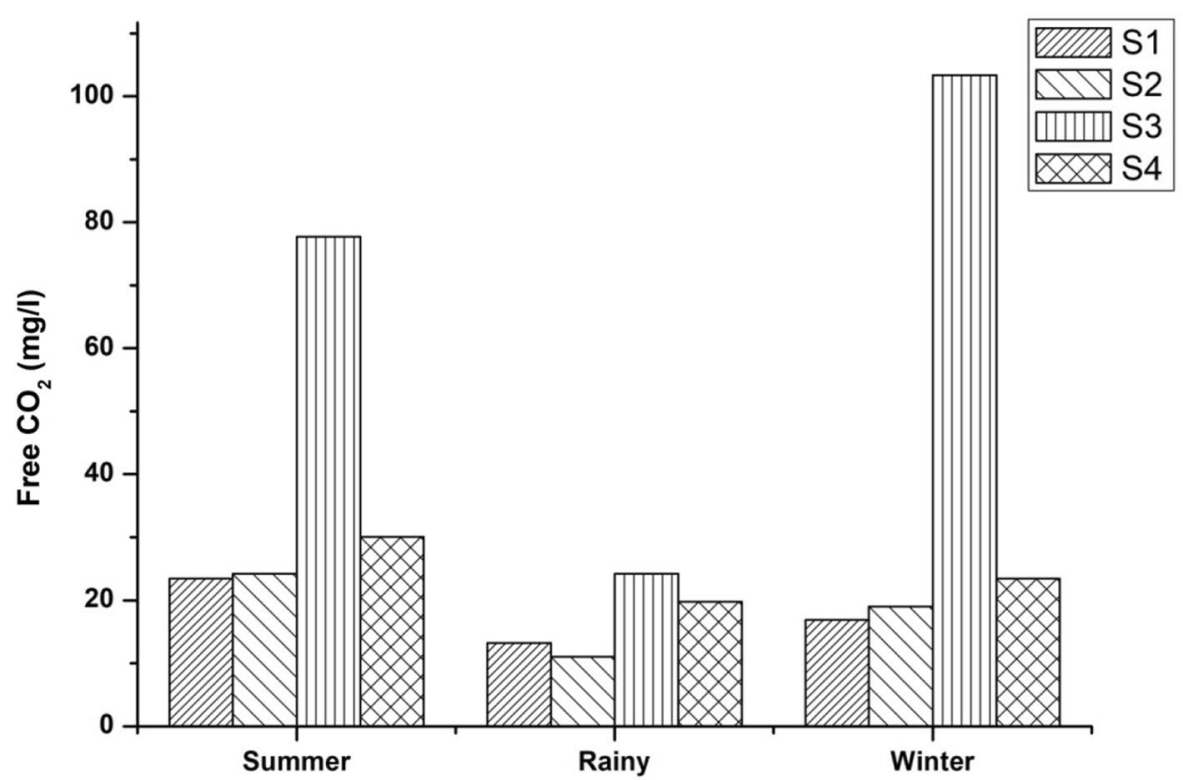

(b) Seasonal variation in Free $\mathrm{CO}_{2}$ at 4 stations
2015). Minimum DO value was obtained at $S 3$ (1 mg/l) in December 2017 and maximum at S2 (8.66 mg/l) in September 2017 (Fig. 5a). Average DO lies within the range $2.93-3.99 \mathrm{mg} / \mathrm{l}$. Seasonal values of DO was maximum during winter at $\mathrm{S} 4(7.63 \mathrm{mg} / \mathrm{l})$ and minimum during summer at $\mathrm{S} 3(1.78 \mathrm{mg} / \mathrm{l})$ as given in Fig. 5b. Maximum DO in winter may be because of low temperature and shorter day length. The anthropogenic activities also change DO due to addition of organic wastes, surface runoff and removal of vegetation, etc. Higher DO in well water during summer may be due to decrease in water level, stagnation of water body, high temperature accompanied with increased microbial activity due to presence of organic waste. DO at S3, i.e., well water, is below the permissible limit given by BIS and WHO (4-6 mg/l) as interpreted in Table 2. Low value of DO at S3 may be due to high temperature in summer accompanied with high rate of respiration of microbes followed by rapid decomposition of organic matter. Values of DO were low when compared with the work reported by Kibami et al (2014) from different ward of Mokokchung town in Nagaland where the value reported ranged from 7.00 to $14.30 \mathrm{mg} / \mathrm{l}$. 
Table 3 The correlation matrix between the various physico-chemical properties of water during rainy season

\begin{tabular}{|c|c|c|c|c|c|c|c|c|c|c|c|}
\hline Parameters & Temp & $\mathrm{pH}$ & DO & BOD & Free $\mathrm{CO}_{2}$ & $\mathrm{Cl}$ & T.alk & T.hard & $\mathrm{Ca}$ hard & $\mathrm{Mg}$ hard & Cond \\
\hline Temp & 1 & & & & & & & & & & \\
\hline $\mathrm{pH}$ & 0.00 & 1 & & & & & & & & & \\
\hline DO & -0.634 & -0.510 & 1 & & & & & & & & \\
\hline BOD & 0.585 & -0.668 & -0.298 & 1 & & & & & & & \\
\hline Free $\mathrm{CO}_{2}$ & -0.842 & -0.445 & 0.938 & -0.336 & 1 & & & & & & \\
\hline Chlorine & -0.528 & -0.552 & $0.991 * *$ & -0.237 & 0.887 & 1 & & & & & \\
\hline T. alk & 0.934 & 0.202 & -0.866 & 0.547 & $-0.966 * *$ & & & & & & \\
\hline T. hard & -0.515 & 0.381 & 0.578 & -0.909 & 0.499 & 0.557 & -0.630 & 1 & & & \\
\hline Ca hard & 0.940 & 0.315 & -0.832 & 0.400 & $-0.971^{*}$ & -0.754 & $0.980 *$ & -0.464 & 1 & & \\
\hline $\mathrm{Mg}$ hard & -0.703 & 0.224 & 0.724 & -0.871 & 0.699 & 0.683 & -0.810 & $0.966^{*}$ & -0.678 & 1 & \\
\hline Cond & 0.733 & 0.555 & $-0.976^{*}$ & 0.239 & $-0.984 *$ & -0.947 & 0.913 & -0.468 & 0.915 & -0.656 & 1 \\
\hline
\end{tabular}

Temp. $=$ Temperature; $\mathrm{DO}=$ Dissolved Oxygen $; \mathrm{BOD}=$ Biological Oxygen Demand $; \mathrm{Cl}=$ Chlorine; abbreviation:T.alk. =Total Alkalinity; $\mathrm{T}$. hard. $=$ Total hardness; $\mathrm{Ca}$ hard. $=$ Calcium hardness; $\mathrm{Mg}$ hard. $=$ Magnesium hardness; Cond. $=$ Conductivity

* Correlation is significant at the 0.05 level (2-tailed); $\mathrm{n}=4 * *$ Correlation is significant at the 0.01 level (2-tailed)

\section{Biological oxygen demand $\left(\mathrm{BOD}_{5}\right)$}

BOD is an indicator of organic pollution with unpolluted natural waters showing a $\mathrm{BOD}_{5}$ of $5 \mathrm{mg} / \mathrm{l}$ or less (Schulze et al. 2001). Lowest $\mathrm{BOD}_{5}$ was observed at $\mathrm{S} 3$ during Nov $2017(0.4 \mathrm{mg} / \mathrm{l})$ and highest at $\mathrm{S} 4(6.85 \mathrm{mg} / \mathrm{l})$ in February 2018 (Fig. 6a). Average BOD $_{5}$ values range from 1.52 to $3.55 \mathrm{mg} / 1$. Seasonal values of BOD $_{5}$ were minimum during winter at $\mathrm{S} 3(0.9 \mathrm{mg} / \mathrm{l})$ and maximum in summer at $\mathrm{S} 2(4.53 \mathrm{mg} / \mathrm{l})$ as depicted in Fig. $6 \mathrm{~b} . \mathrm{BOD}_{5}$ was inversely related to $\mathrm{DO}$. The raised levels of $\mathrm{BOD}_{5}$ in summer season indicate the extent of organic pollution which undergoes biotic decomposition (Jonnalagadda et al. 2001).

\section{Total alkalinity}

The alkalinity of water is due to the presence of mineral salts, primarily carbonate and bicarbonate ions, present in it. Alkalinity makes water tasteful and helps in coagulation (Hussain 1987); nonetheless, it is preferable at less than $100 \mathrm{mg} / \mathrm{l}$ for domestic use. Lowest monthly variation in total alkalinity was found in September 2017 at S3 (15 mg/l) and also maximum in December 2017 at S3 (42 mg/l) as shown in Fig. 7a. Average total alkalinity lies within the range $18.32-30.28 \mathrm{mg} / \mathrm{l}$ (Table 2). Seasonally, the value of total alkalinity was found to be low during rainy season at $\mathrm{S} 3(15 \mathrm{mg} / \mathrm{l})$ and high in winter $(49.5 \mathrm{mg} / \mathrm{l})$ at S2 (Fig. 7b). According to ISI the desired limit and the maximum permissible limit for alkalinity in drinking water are 200 and $600 \mathrm{mg} / \mathrm{l}$, respectively (Table 2). Therefore, the values of total alkalinity content in all sampling stations have been found to be low as compared to desired limit value.

\section{Chloride}

Sources of chloride in natural water may be from soil, municipal or industrial sewage and wastes of animal origin (Girija et al. 2017) and often serve as a chemical pollution indicator for sewage contamination. Chloride content in potable water is given by WHO (1983) in $250 \mathrm{mg} / \mathrm{l}$. Lowest chloride content was recorded at S4 $(19.88 \pm 0.02 \mathrm{mg} / \mathrm{l})$ in November 2017 and highest at S3 (79.52 mg/l) in September 2017 (Fig. 8a). Average chloride values lie within the range $32.25-38.34 \mathrm{mgl} /$ (Table 2). Seasonally, chloride content was higher during rainy season at $\mathrm{S} 3(79.52 \mathrm{mg} / \mathrm{l})$ and lower during winter $(26.98 \mathrm{mg} / \mathrm{l})$ at $\mathrm{S} 4$ (Fig. $8 \mathrm{~b})$. The high content of chloride during rainy season in well water (S3) may be due to storage of accumulated sewage during rainy season coupled with decaying process that accomplished by the microbes (Kumar et al 2005). Higher value of during rainy season in well water may be due to leached from rocks and water by weathering. The concentration of chloride was found within the permissible limit of BIS $(250 \mathrm{mg} / \mathrm{l})$, thus indicating the absence of chloride pollution sources. Values of $\mathrm{Cl}$ were within the range reported by Kibami et al (2014) from Mokokchung town $(11.36-63.90 \mathrm{mg} / \mathrm{l})$ except the value in $\mathrm{S} 3$; the value of $\mathrm{Cl}$ is greater than their values.

\section{Electrical conductivity}

It is a measure of capacity of a solution to carry an electrical current and is a total parameter for dissolved and dissociated substances which also indicates the concentration of dissolved electrolytes. Minimum conductivity value was reported at S3 $(38.4 \mu \mathrm{S} / \mathrm{cm})$ in September 2017 and maximum in March 2018 at S4 with a value of $272 \mu \mathrm{S} / \mathrm{cm}$ (Fig. 9a). Seasonally the value of conductivity was found to 
Fig. 5 a Monthly variation in dissolved oxygen (DO) from the 4 sampling stations. b Seasonal variation in dissolved oxygen (DO) from the 4 sampling stations

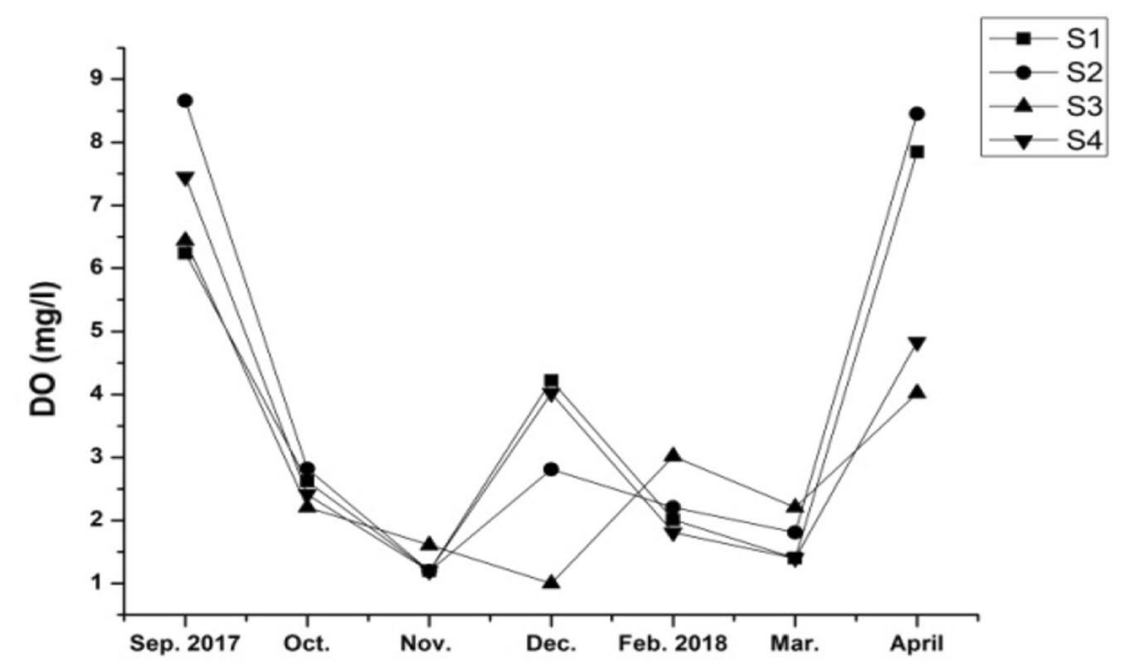

(a) Monthly variation in Dissolved Oxygen (DO) at 4 stations

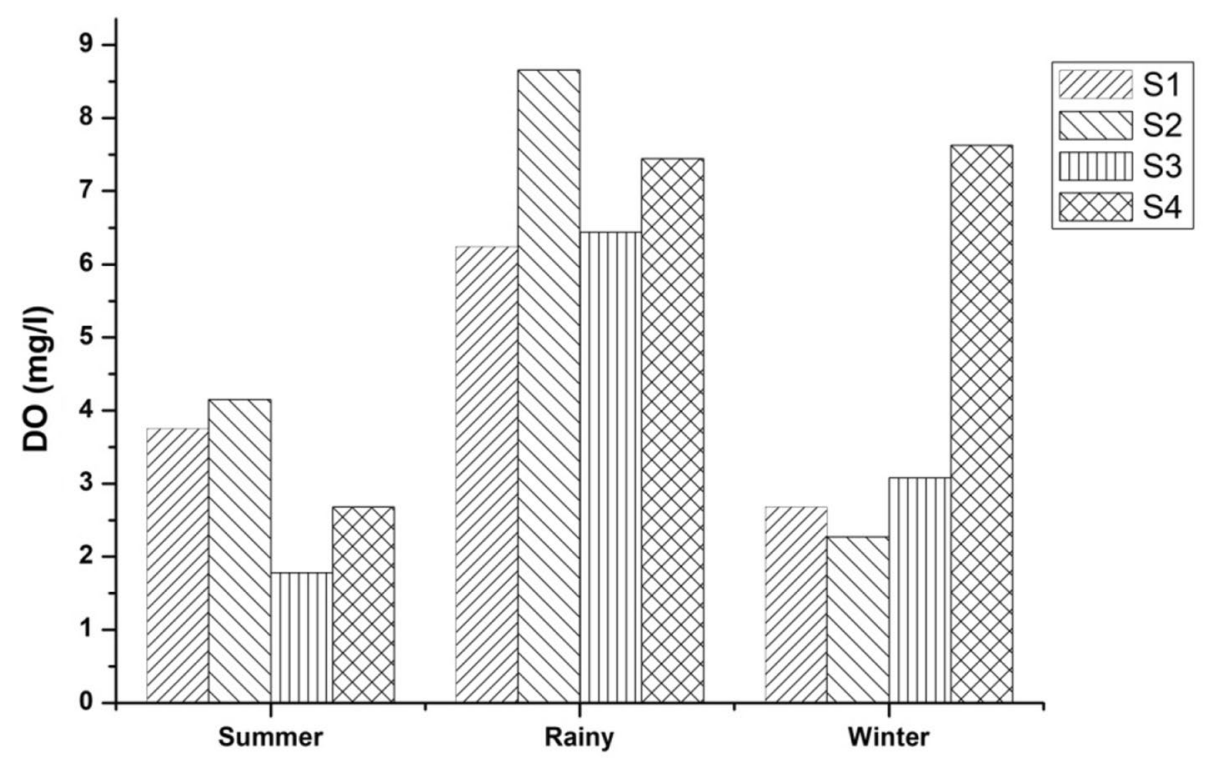

(b) Seasonal variation in Dissolved Oxygen (DO) at 4 stations be highest during summer $(249.9 \mu \mathrm{S} / \mathrm{cm})$ at $\mathrm{S} 2$ and lowest during rainy season $(38.4 \mu \mathrm{S} / \mathrm{cm})$ at $\mathrm{S} 3$ as given in Fig. $9 \mathrm{~b}$. In the present study, the average values of electrical conductivity ranged from 91.41 to $115 \mu \mathrm{S} / \mathrm{cm}$ which is very low when compared with the standard limit for drinking water given by WHO $(750 \mu \mathrm{S} / \mathrm{cm})$ indicating good water quality (Table 2).

\section{Total hardness}

Total hardness is the parameter of water quality used to describe the effect of dissolved minerals (mostly $\mathrm{Ca}$ and $\mathrm{Mg}$ ), determining suitability of water for domestic, industrial and drinking purposes. Minimum value of hardness was observed at S1 in April $2018(28 \mathrm{mg} / \mathrm{l})$ and maximum at S3 in March 2018 (370 mg/l) as depicted in Fig. 10a. Average total hardness ranges from 54.85 to $138.57 \mathrm{mg} / \mathrm{l}$ (Table 2). Seasonally, total hardness was maximum during summer at S3 (180.66 mg/l) and minimum during winter at $\mathrm{S} 1(42.66 \mathrm{mg} / \mathrm{l})$ as shown in Fig. 10b. Higher values of total hardness at S3 (well water) during summer may be due to natural accumulation of salts and decrease in water volume due to less rainfall. Moshood (2008) opined that decreased hardness in winter may be due to more productivity in this season. The desirable limit of total hardness in potable water is $300 \mathrm{mg} / \mathrm{l}$ as given by Indian standards for drinking water (Table 2). Except S3 in well water which is near to the permissible limit, the remaining stations are safe for drinking 
Fig. 6 a Monthly variation in biological oxygen demand (BOD) from the 4 sampling stations. b Seasonal variation in biological oxygen demand (BOD) from the 4 sampling stations

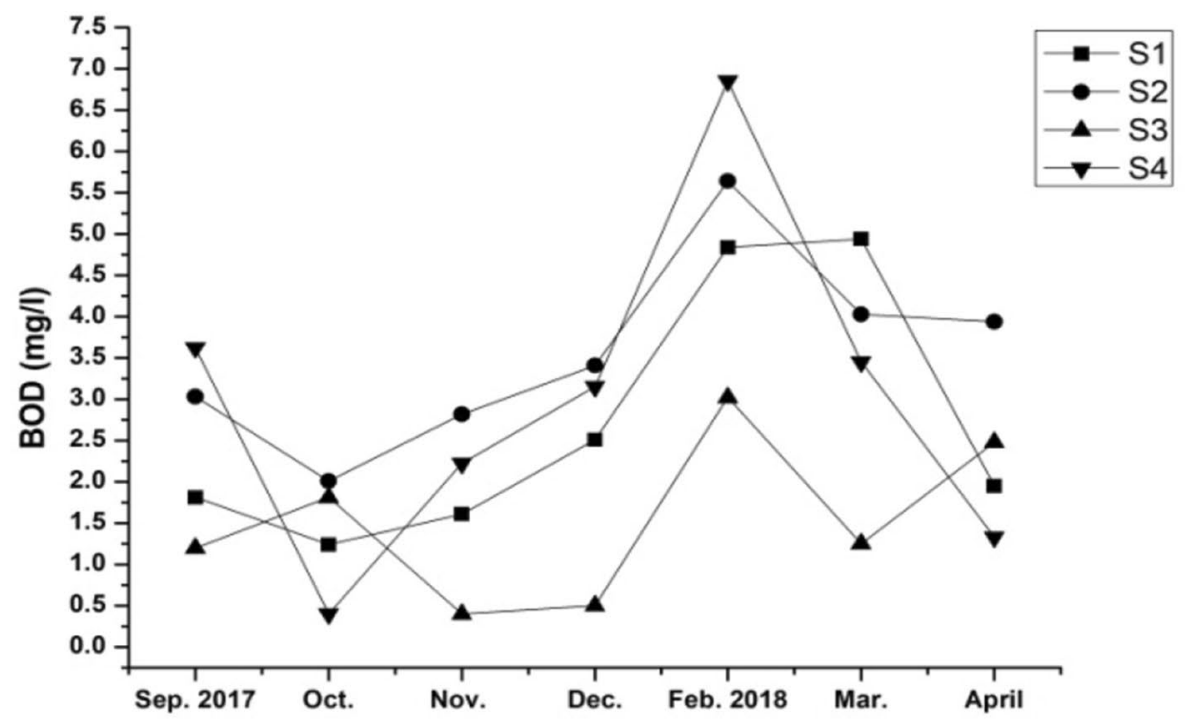

(a) Monthly variation in Biological Oxygen Demand (BOD) at 4 stations

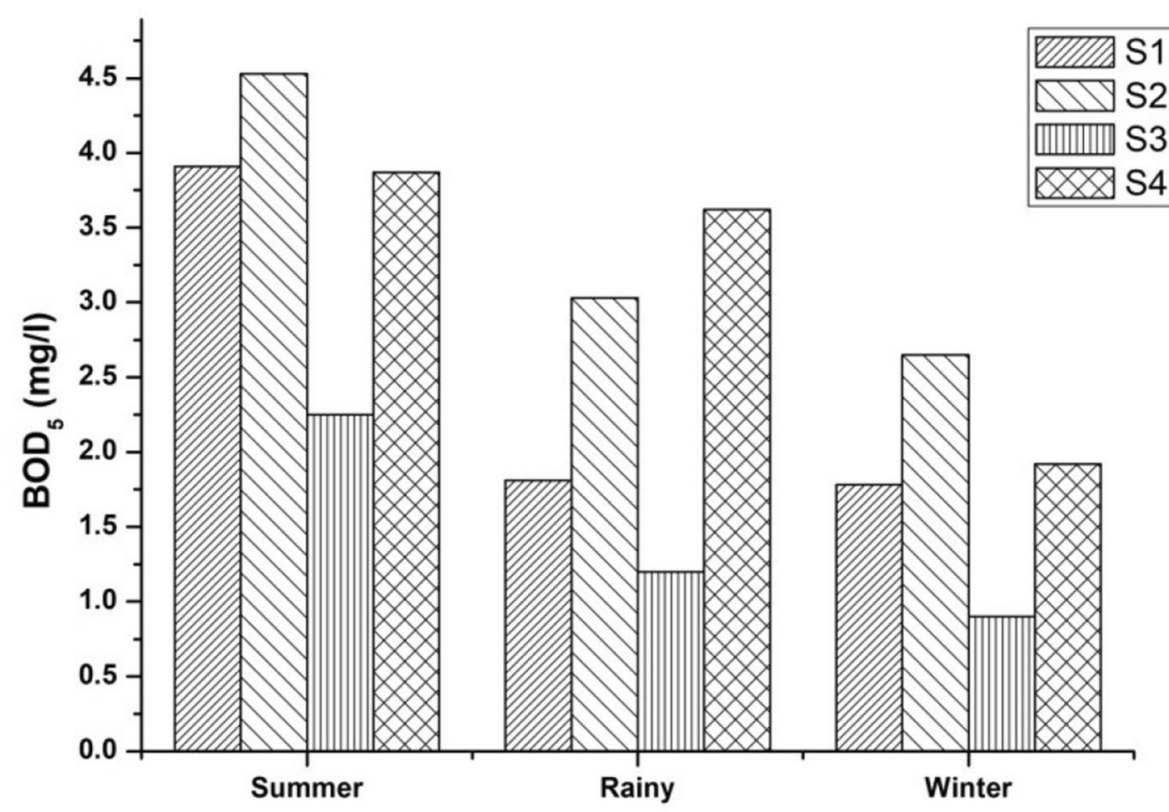

(b) Seasonal variation in Biological Oxygen Demand (BOD) at 4 stations and domestic uses. Values of total hardness were within the range reported by Kibami et al (2014) in Mokokchung town $(55-150 \mathrm{mg} / \mathrm{l})$ except the value of S3 $(180.66 \mathrm{mg} / \mathrm{l})$ is greater than the value reported by them.

\section{Calcium hardness as $\mathrm{CaCO}_{3}$}

Minimum value of $\mathrm{Ca}$ hardness as $\mathrm{CaCO}_{3}$ was exhibited at S4 in April 2018 (10.5 mg/l) and maximum also in December at S3 (134.4 mg/l) as given in Fig. 11a.
Average values ranged from 21.90 to $64.80 \mathrm{mg} / \mathrm{l}$. Seasonal value was highest during summer $(161 \mathrm{mg} / \mathrm{l})$ at $\mathrm{S} 3$ and lowest in winter (14 mg/l) at $\mathrm{S} 1$ as shown in Fig. $11 \mathrm{~b}$. High content of $\mathrm{Ca}$ hardness at $\mathrm{S} 3$ (well water) may be due to the application of lime during April 2017 as disinfectant and is beyond the permissible limit setup by BIS and WHO $(75 \mathrm{mg} / \mathrm{l})$ as illustrated in Table 2. Values of $\mathrm{Ca}$ hardness were comparatively higher than the value recorded by Kibami et al (2014) from Mokokchung town. 
Fig. 7 a Monthly variation in total alkalinity from the 4 sampling stations. b Seasonal variation in total alkalinity from the 4 sampling stations

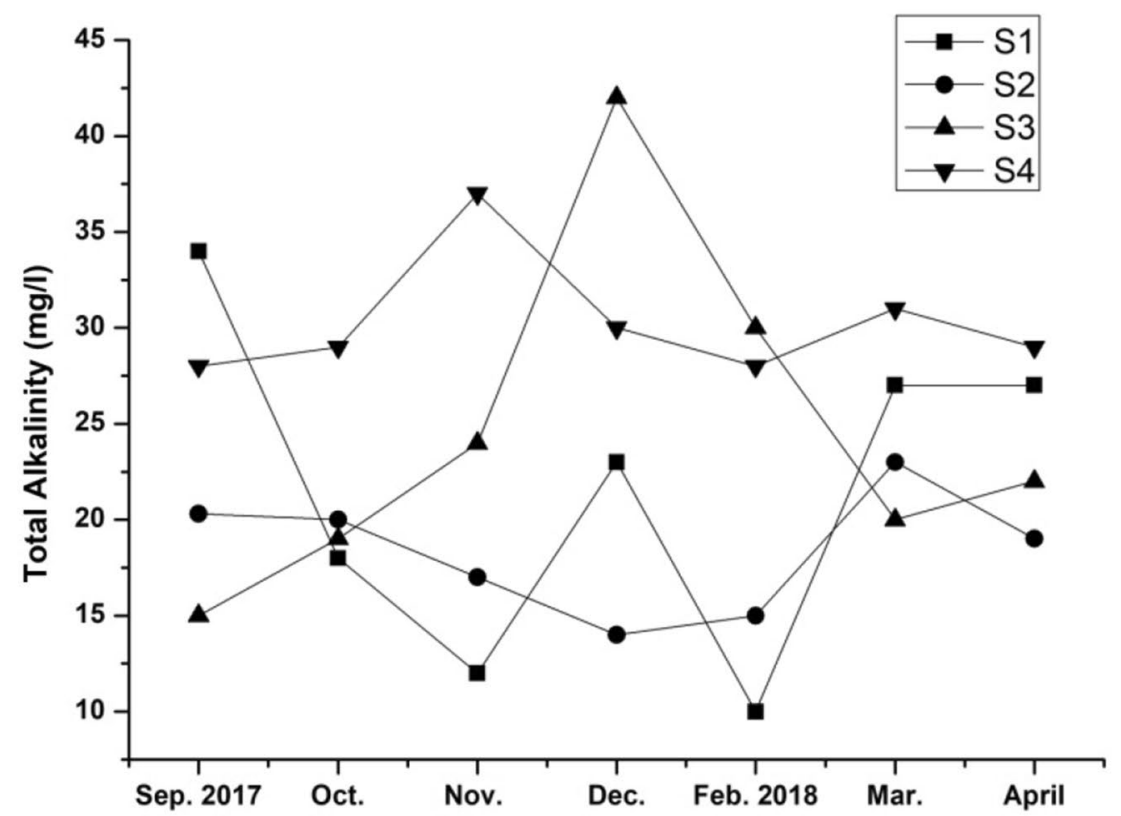

(a) Monthly variation in Total Alkalinity at 4 stations

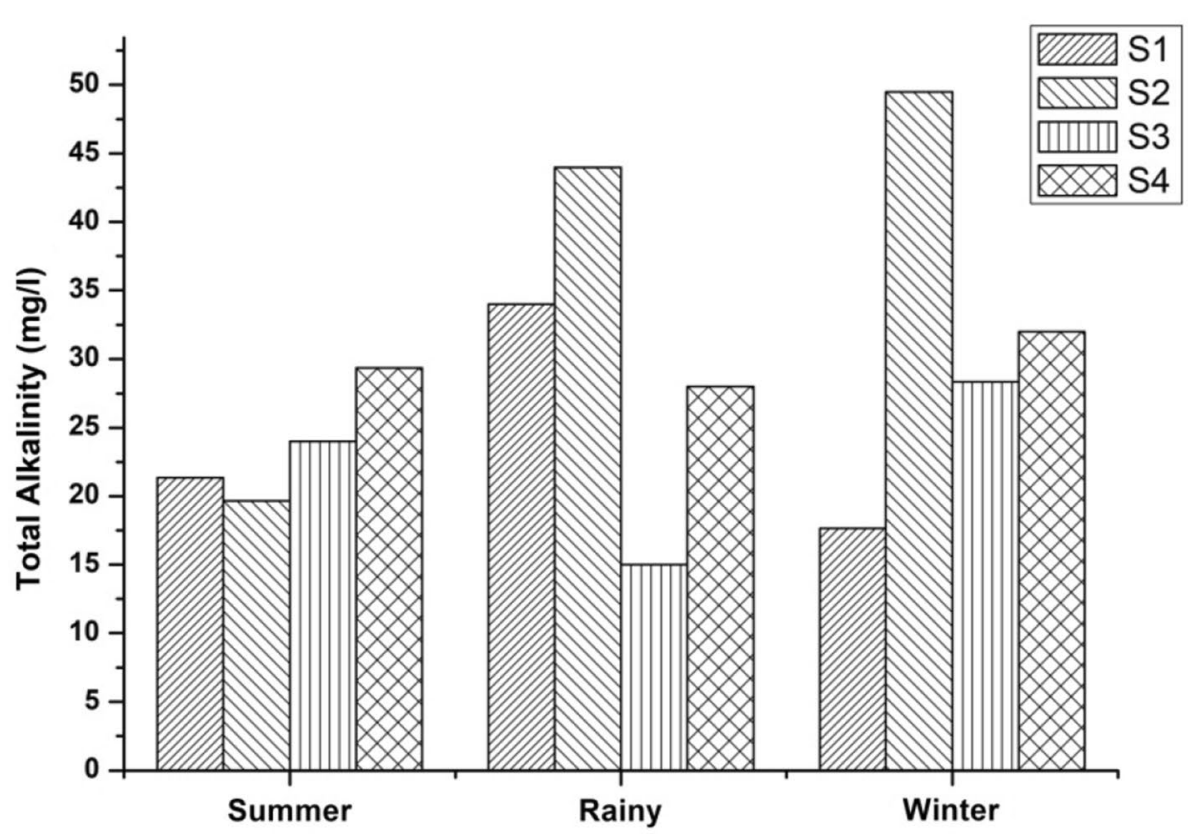

(b) Seasonal variation in Total Alkalinity at 4 stations

\section{Magnesium hardness}

Minimum value of $\mathrm{Mg}$ hardness was recorded at S3 $(0.21 \mathrm{mg} / \mathrm{l})$ in April 2018 and maximum in September 2017 at $\mathrm{S} 3(31.35 \mathrm{mg} / \mathrm{l})$ as depicted in Fig. 12a. Average values ranged from 7.05 to $9.76 \mathrm{mg} / \mathrm{l}$ as shown in Table 3. Seasonal value was highest during rainy season $(31.35 \mathrm{mg} / \mathrm{l})$ at $\mathrm{S} 3$ and lowest during summer $(3.88 \mathrm{mg} / \mathrm{l})$ at $\mathrm{S} 3$ as given in Fig. 12b. Mg hardness obtained in the present study was within the range as obtained by Kibami et al (2014), i.e., $2.43-15.10 \mathrm{mg} / \mathrm{l}$ except the value of $\mathrm{S} 3(31.35 \mathrm{mg} / \mathrm{l})$ in well water is higher than their recorded values.

\section{Correlation among the physico-chemical parameters of water}

A good relationship between two variables is indicated by a correlation coefficient value near 1 or -1 , whereas a value 
Fig. 8 a Monthly variation in chloride from the 4 sampling stations. b Seasonal variation in chloride from the 4 sampling stations

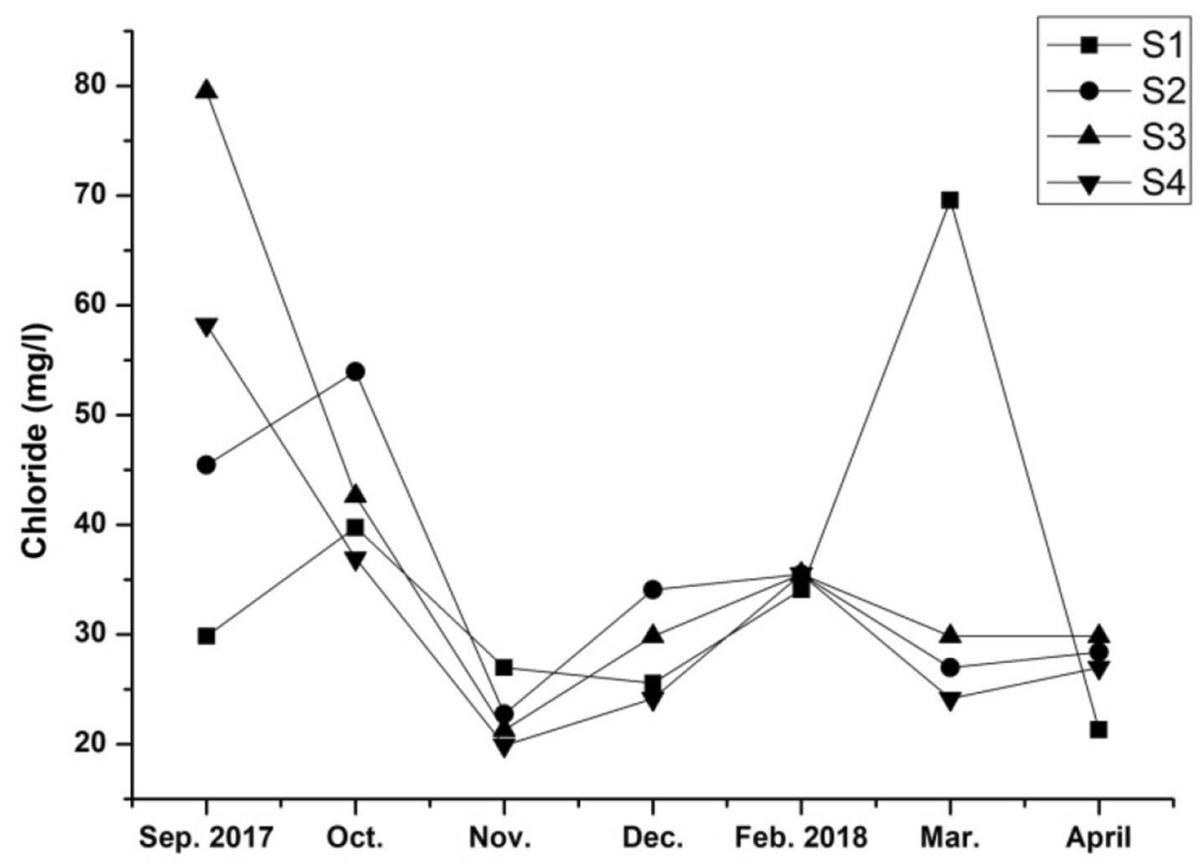

(a) Monthly variation in Chloride at 4 stations

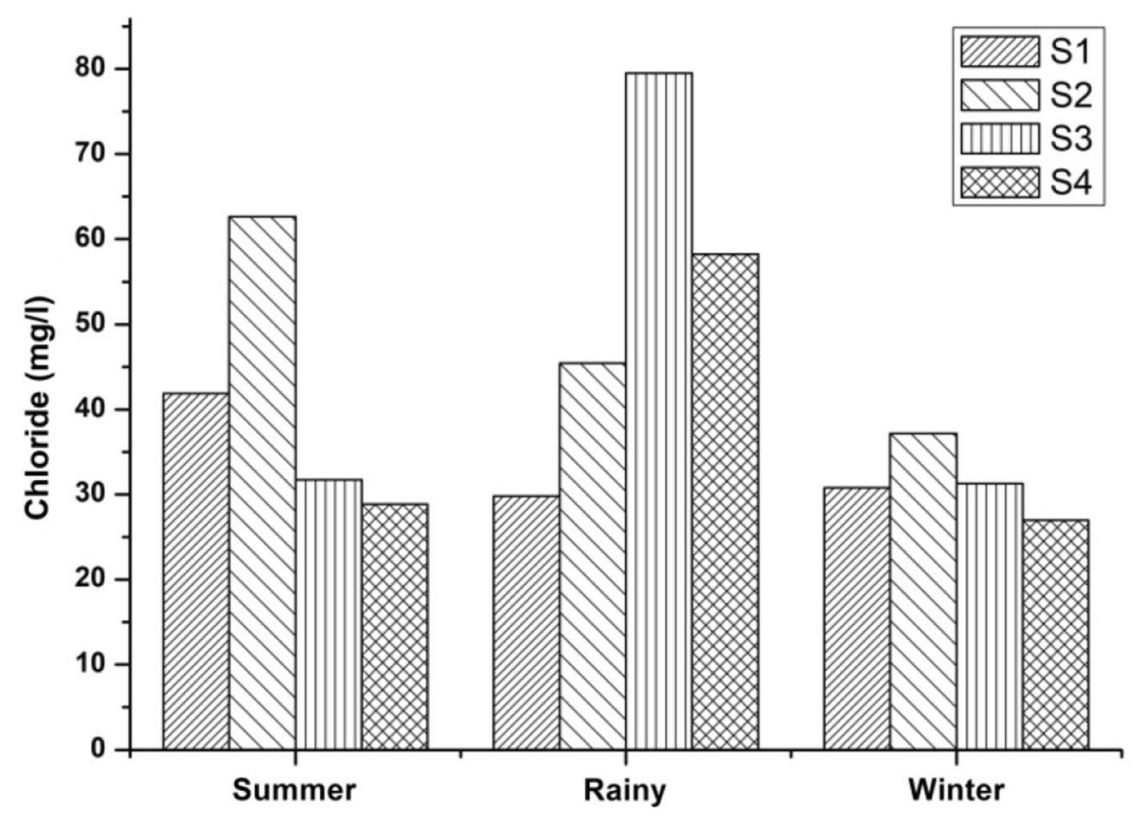

(b) Seasonal variation in Chloride at 4 stations around zero indicates the absence of relationship. Similarly, a strong correlation between the parameters is characterized by a positive value in the range of +0.8 to 1.0 , while negative values of $r$ indicate an inverse relationship. The larger the numerical value of the correlation coefficient $(r>0.8)$, the greater is the extent to which correlation holds between the two variables. Tables 3, 4 and 5 show the relationship between water quality parameters for three different seasons (summer, rainy and winter) using correlation matrix analysis.

During rainy season, chlorine was found to be highly significant positively with DO $(\mathrm{p}<0.05)$ and negatively with free $\mathrm{CO}_{2}(\mathrm{p}<0.05)$, and $\mathrm{Ca}$ hardness shows significant negative correlation with free $\mathrm{CO}_{2}(\mathrm{p}<0.05)$ and positively with alkalinity $(\mathrm{p}<0.05)$. Conductivity was found to be highly significant negatively with free $\mathrm{CO}_{2}$ 
Fig. 9 a Monthly variation in conductivity from the 4 sampling stations. b Seasonal variation in conductivity from the 4 sampling stations

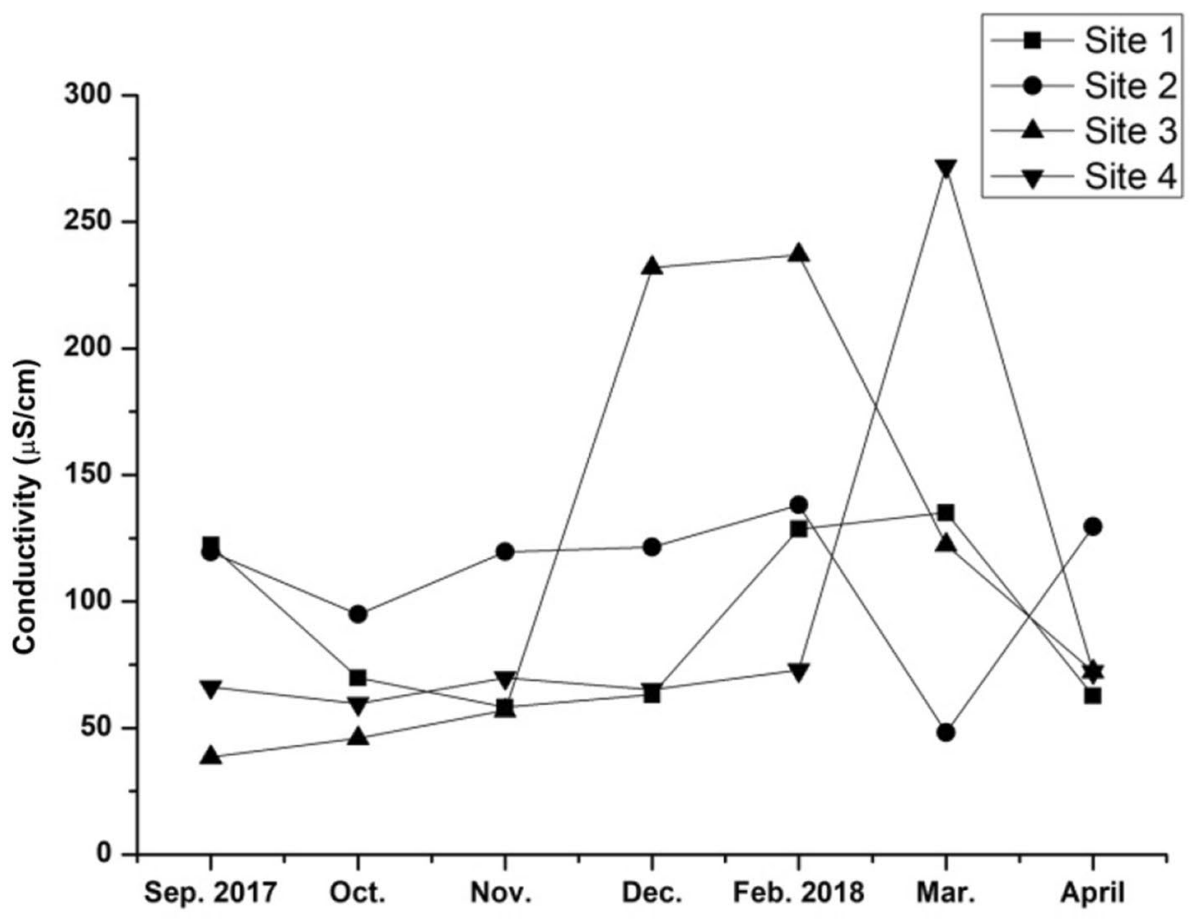

(a) Monthly variation in Conductivity at 4 stations

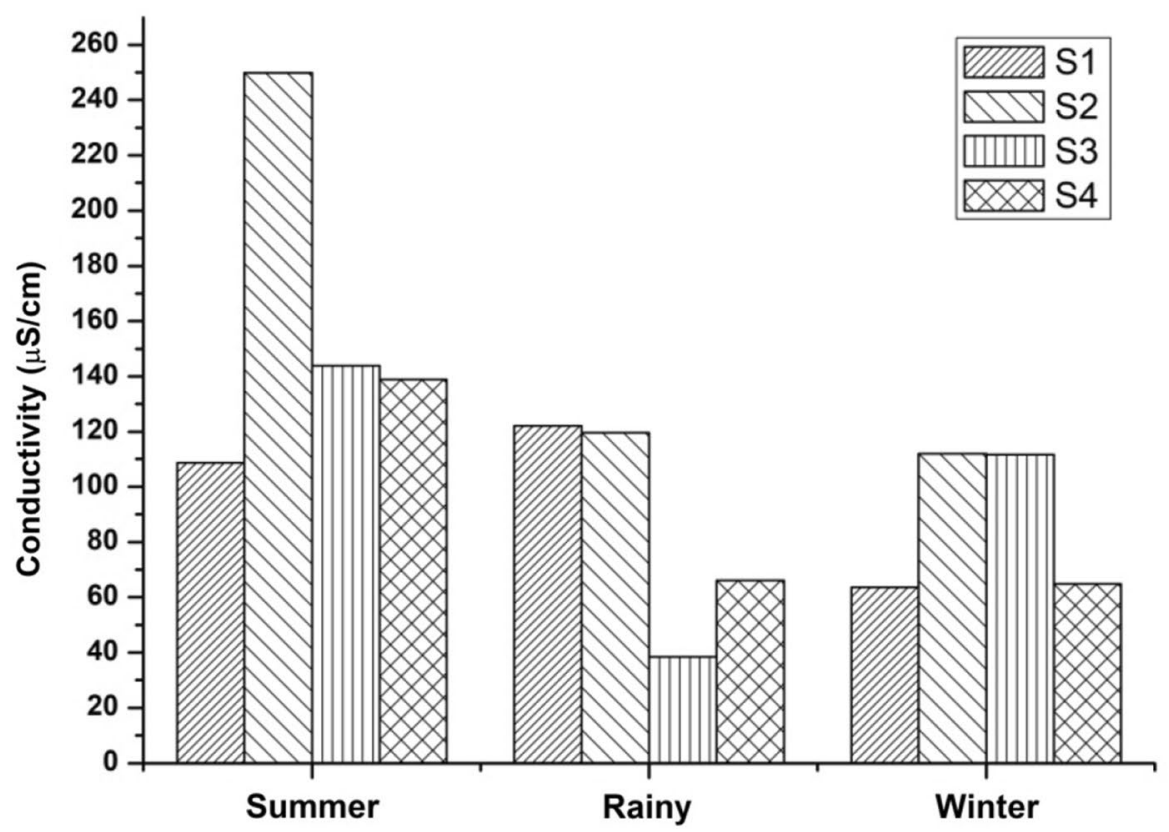

(b) Seasonal variation in Conductivity at 4 stations and DO at $\mathrm{p}<0.05$ level (Table 3). Significant positive correlation between $\mathrm{Ca}$ hardness and alkalinity is due to the presence of carbonates, bicarbonates and hydroxides causing alkalinity in water (Sharma and Jain 2006). In summer, highly significant negative correlation was found between free $\mathrm{CO}_{2}$ with $\mathrm{BOD}, \mathrm{Mg}$ hardness with temperature at $\mathrm{p}<0.05$ level (Table 4 ). In winter, significant positive correlation at $\mathrm{p}<0.05$ level was observed for BOD with $\mathrm{pH}, \mathrm{Ca}$ hardness and temperature, total hardness with Ca hardness, conductivity with total hardness, while significant positive correlation at $p<0.01$ level was observed for alkalinity with $\mathrm{Mg}$ hardness (Table 5). The highly significant correlation between BOD and $\mathrm{pH}$ is due to high microbial decomposition taking place in 
Fig. 10 a Monthly variation in total hardness from the 4 sampling stations. b Seasonal variation in total hardness from the 4 sampling stations

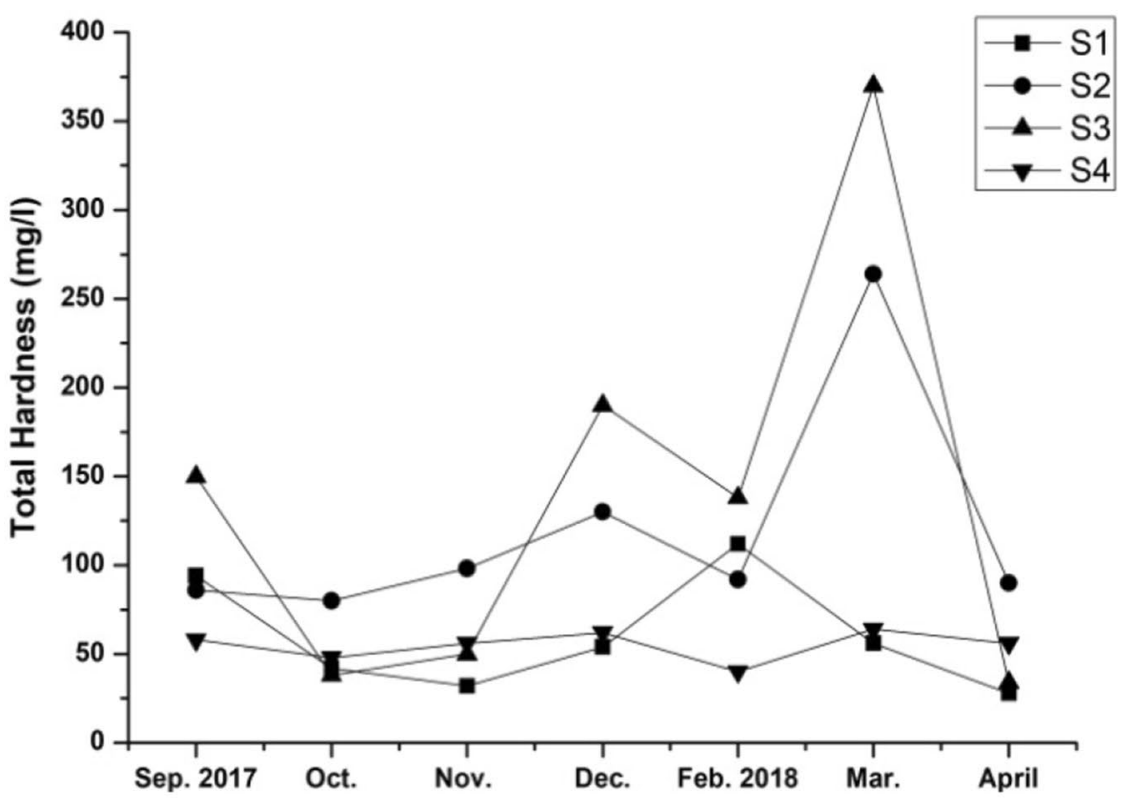

(a) Monthly variation in Total hardness at 4 stations

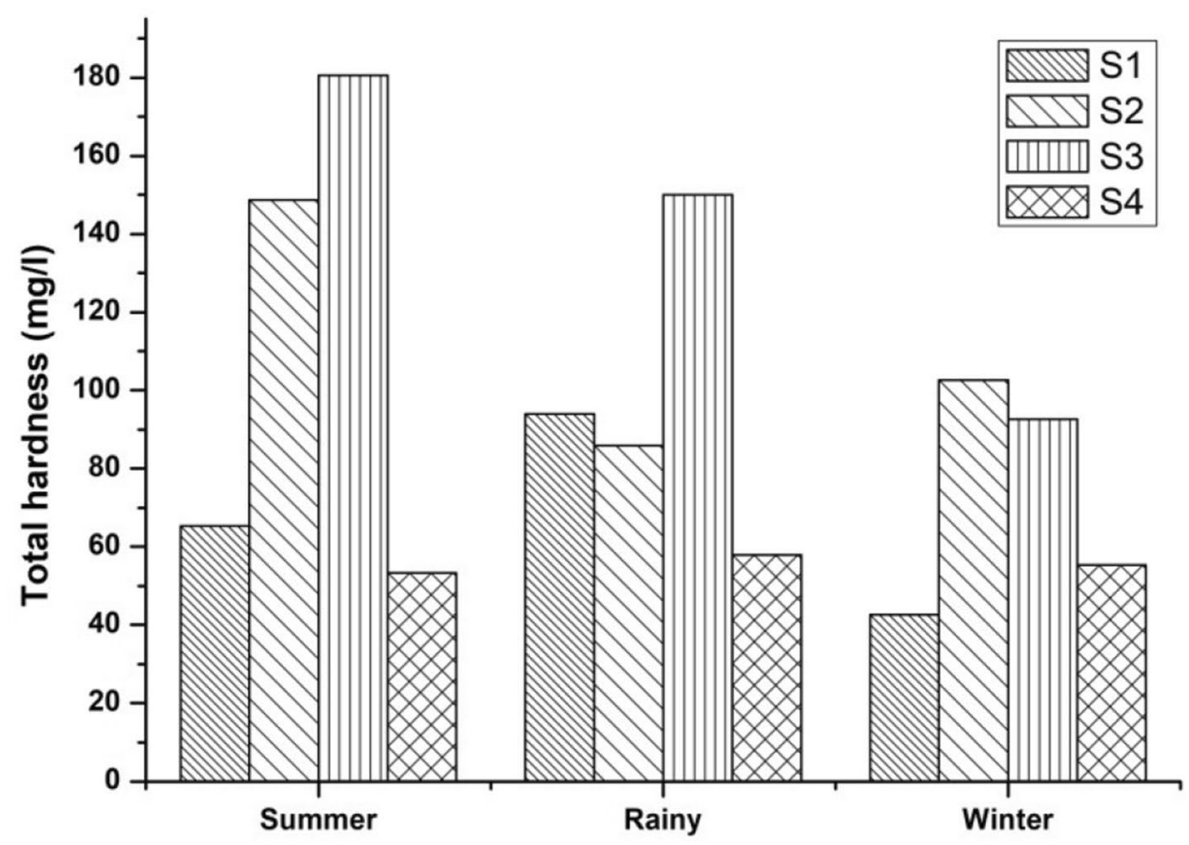

(b) Seasonal variation in Total hardness at 4 stations the water bodies followed by formation of carbonic acid imparting acidity nature. During rainy season, conductivity was found to be strongly interrelated with temperature $\left(r^{2}=+0.834\right), C l\left(r^{2}=-0.947\right)$, alkalinity $\left(r^{2}=+0.913\right)$, Ca hardness $\left(r^{2}=+0.915\right)$ and $\mathrm{Mg}$ hardness $\left(r^{2}=-0.656\right)$. Free $\mathrm{CO}_{2}$ shows strong relation with temperature, chlorine and $\mathrm{DO}\left(\mathrm{r}^{2}=-0.842,+0.887\right.$ and +0.938$)$. Alkalinity was found to correlate strongly with temperature, $\mathrm{DO}, \mathrm{Cl}$, $\mathrm{pH}$ with $\mathrm{r}^{2}=0.934,-0.866,-0.794,-0.807$ and -0.827 , respectively. Total hardness shows strongly interrelated with BOD and temperature $\left(\mathrm{r}^{2}=-0.909\right.$ and -0.889$)$ as illustrated in Table 3. Electrical conductivity was found to be significant with alkalinity which may be due to the presence of chloride ion imparting as electrolytes. In summer, a strong correlation exists between free $\mathrm{CO}_{2}$ with DO $\left(r^{2}=-0.858\right)$, chlorine with DO $\left(r^{2}=0.838\right)$, total hardness with temperature $\left(r^{2}=0.825\right)$ as shown in Table 5 . In 
Fig. 11 a Monthly variation in calcium hardness from the 4 sampling stations. b Seasonal variation in calcium hardness from the 4 sampling stations

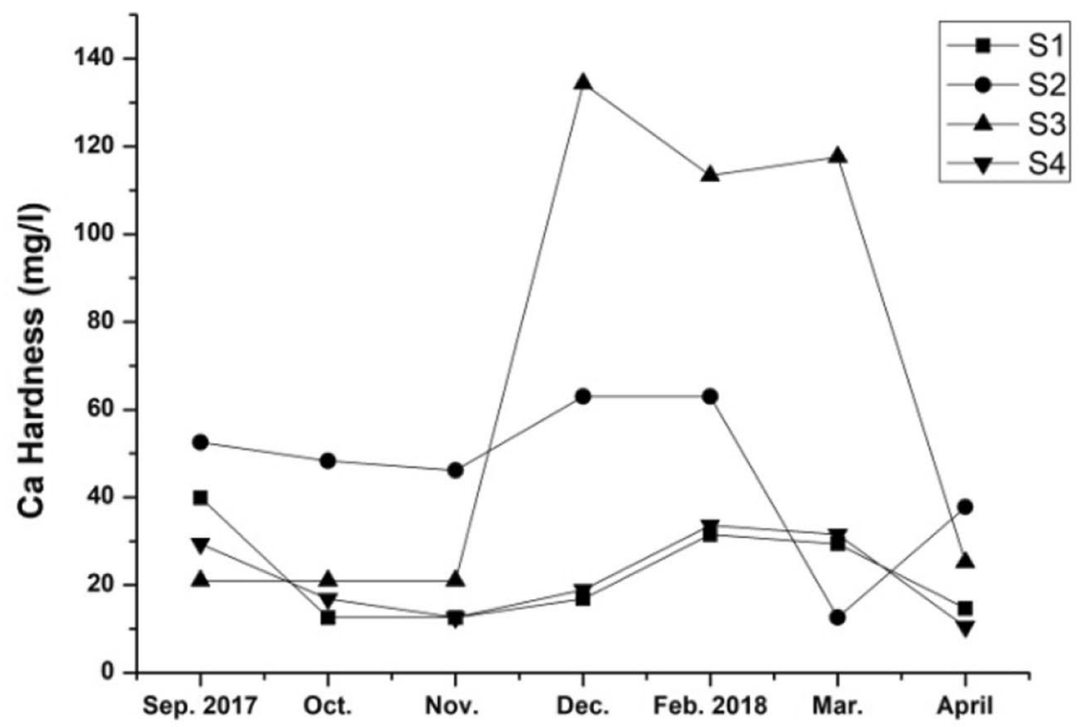

(a) Monthly variation in Calcium hardness at 4 stations

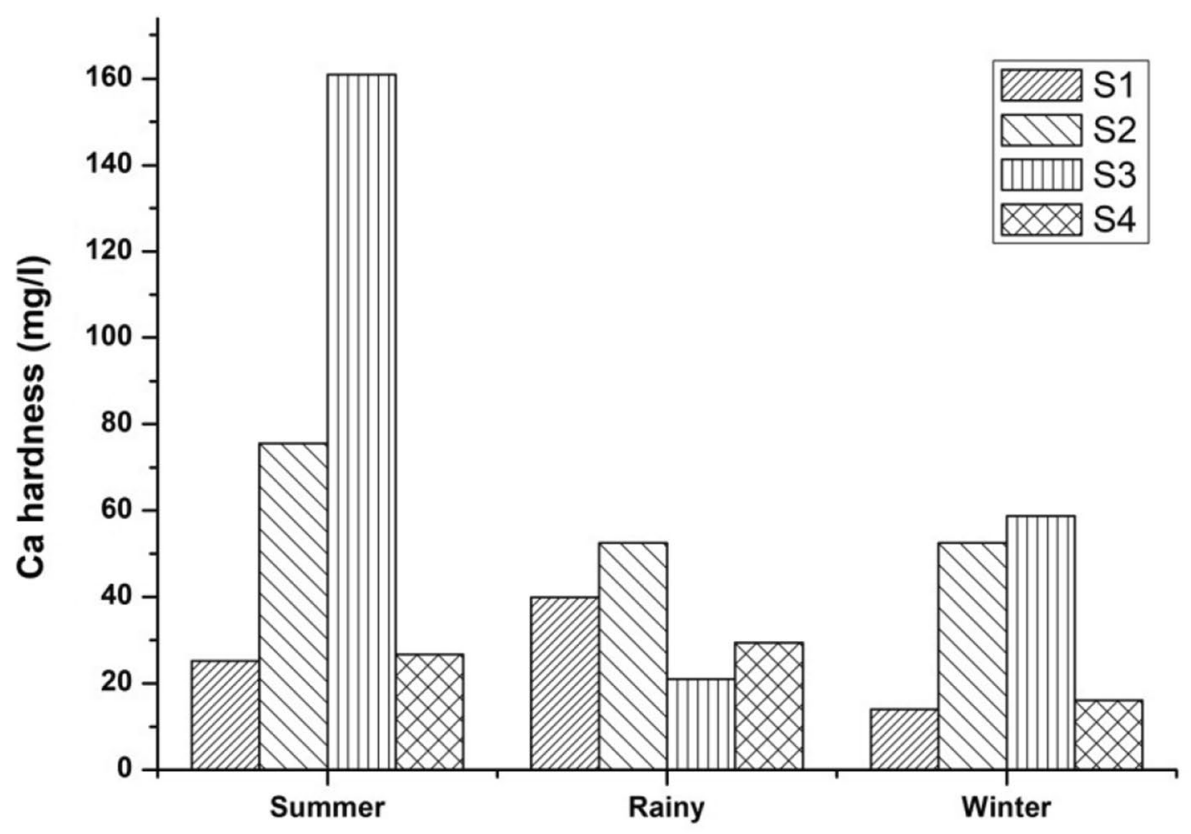

(b) Seasonal variation in Calcium hardness at 4 stations winter, strongly interrelated variables in physico-chemical parameters were observed for free $\mathrm{CO}_{2}$ with temperature, $\mathrm{pH}$ and $\mathrm{BOD}\left(\mathrm{r}^{2}=0.832,-0.943\right.$ and -0.847$)$. Chlorine was found to correlate strongly with DO $\left(\mathrm{r}^{2}=-0.792\right)$ as given in Table 5. Positive correlation for free $\mathrm{CO}_{2}$ with temperature is due to low temperature in winter lowering the activities of microbial decomposition accompanied with less respiration. Negative correlation of free $\mathrm{CO}_{2}$ with $\mathrm{pH}$ indicates that with increase in $\mathrm{CO}_{2}$, carbonic acid is formed, hence imparting acidity nature of water.

\section{Heavy metal concentrations}

\section{Arsenic}

The presence of toxic arsenic in drinking water has been an inevitable concern for many years due to its occurrence in natural environmental media usually present in the form of compounds with sulfur and with many metals. Apart from that naturally occurring in spring waters, arsenic is primarily sourced from industrial discharges and also enters into ground water through underground rocks, 
Fig. 12 a Monthly variation in magnesium hardness from the 4 sampling stations. b Monthly variation in magnesium hardness from the 4 sampling stations

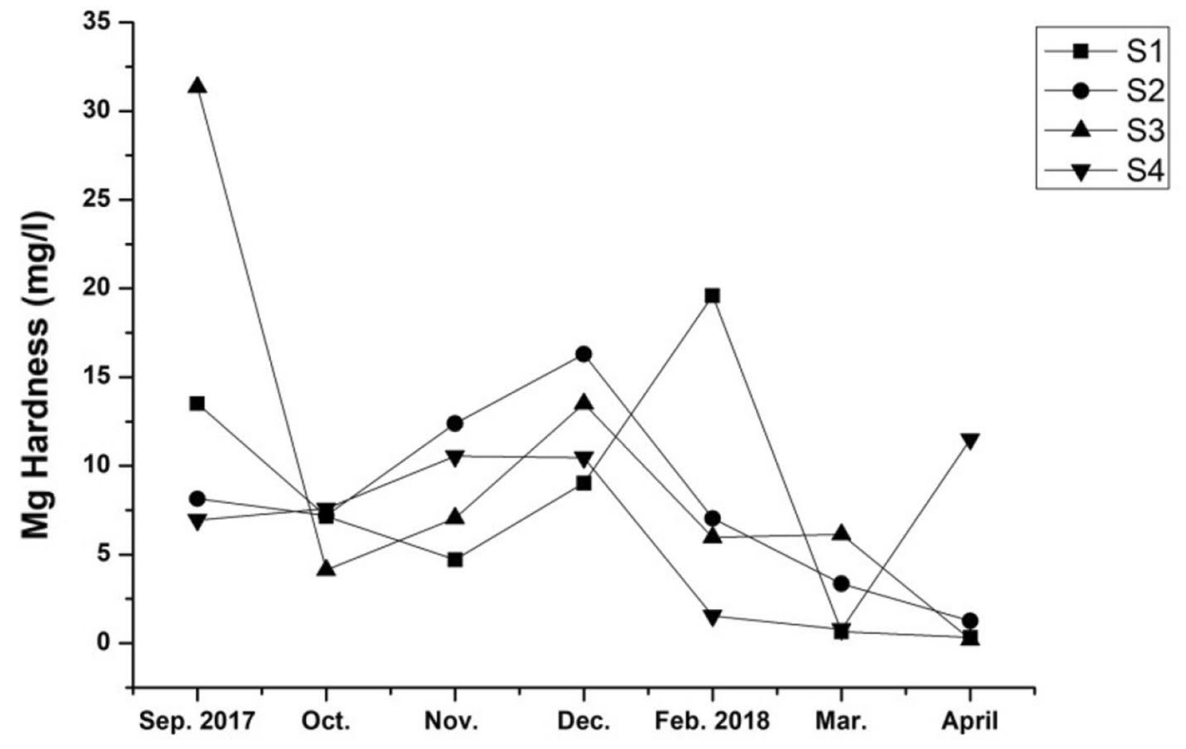

(a) Monthly variation in Magnesium hardness at 4 stations

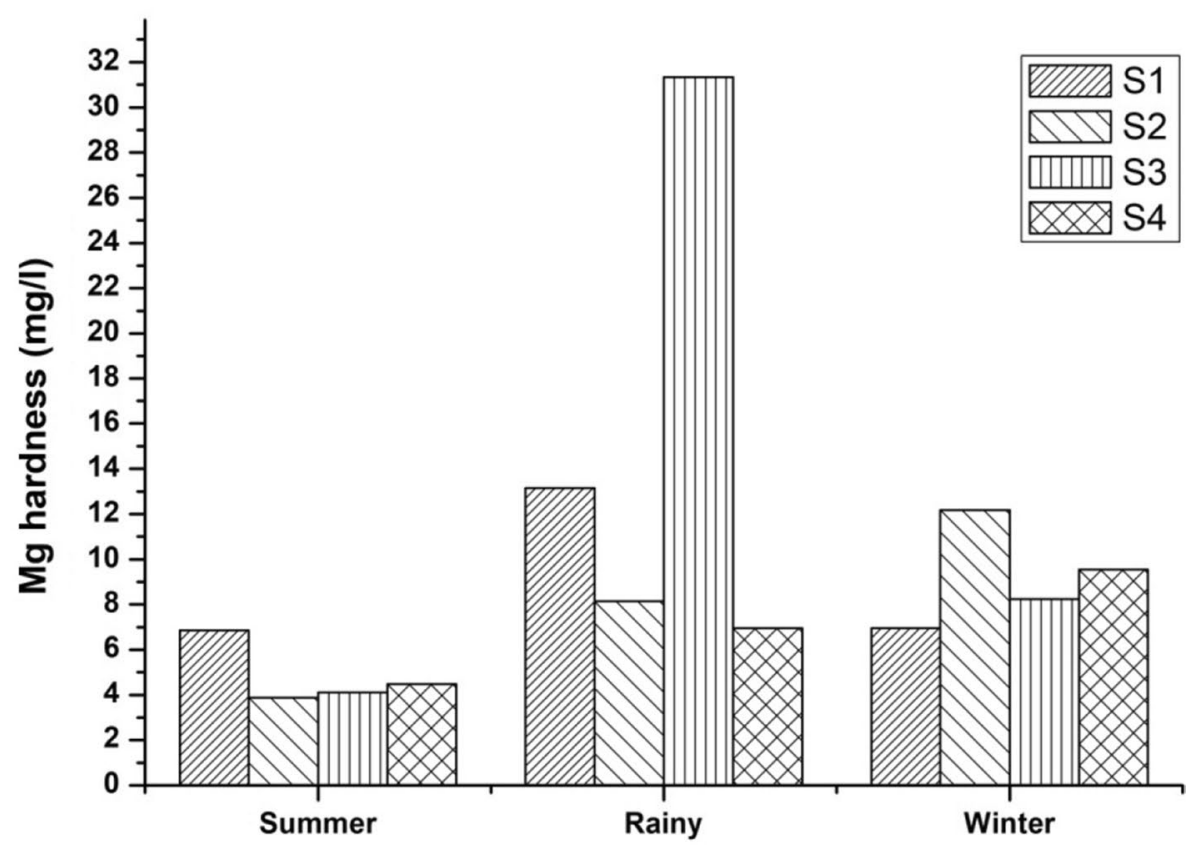

(b) Seasonal variation in Magnesium hardness at 4 stations soil and industrial human activities. Increased concentration of arsenic can cause problems to skin, circulatory and nervous system. Daily consumption of water with greater than $0.01 \mathrm{mg} / \mathrm{l}$ of As, less than $0.2 \%$ of the fatal dose, can on long term lead to problems with the skin as well as circulatory and nervous systems. The maximum acceptable concentration of arsenic in drinking water recommended by the World Health Organization is $10 \mu \mathrm{g} / \mathrm{l}$. In our study none of the samples were found detected the presence of arsenic.

\section{Cadmium}

Cadmium is uniformly distributed in trace amounts in the earth's crust and is highly toxic and responsible for several cases of food poisoning. Small quantities of $\mathrm{Cd}$ cause adverse changes in the arteries of human kidneys. Cadmium enters water through industrial discharges or the deterioration of galvanized pipes and can be present in groundwater from a wide variety of sources in the environment and from industry. In the present study, all samples have been found 
to be exceeding the WHO standards. The concentration of $\mathrm{Cd}$ in all the four sampling stations was $0.02 \mathrm{mg} / \mathrm{l}$ (Table 6) which is higher than the permissible limit given by WHO
$(0.005 \mathrm{mg} / \mathrm{l})$ and ISI $(0.01 \mathrm{mg} / \mathrm{l})$. The concentration of $\mathrm{Cd}$ in all the sampling station is higher than the value obtained by Jamir et al (2011) in five district of Nagaland (0.001 to

Table 4 The correlation matrix between the various physico-chemical properties of water during summer season

\begin{tabular}{|c|c|c|c|c|c|c|c|c|c|c|c|}
\hline Parameters & Temp & $\mathrm{pH}$ & DO & BOD & Free $\mathrm{CO}_{2}$ & $\mathrm{Cl}$ & T.alk & T. hard & Ca hard & $\mathrm{Mg}$ hard & $\overline{\text { Cond }}$ \\
\hline Temp & 1 & & & & & & & & & & \\
\hline $\mathrm{pH}$ & 0.253 & 1 & & & & & & & & & \\
\hline DO & -0.299 & 0.832 & 1 & & & & & & & & \\
\hline BOD & -0.270 & 0.670 & 0.900 & 1 & & & & & & & \\
\hline Free $\mathrm{CO}_{2}$ & 0.522 & -0.491 & -0.858 & $-0.961 *$ & 1 & & & & & & \\
\hline $\mathrm{Cl}$ & 0.231 & $0.999 * *$ & 0.838 & 0.662 & -0.489 & 1 & & & & & \\
\hline T. alk & -0.061 & -0.807 & -0.648 & -0.271 & 0.175 & -0.827 & 1 & & & & \\
\hline T. hard & 0.825 & 0.289 & -0.267 & -0.487 & 0.690 & 0.288 & -0.439 & 1 & & & \\
\hline Ca hard & 0.744 & -0.083 & -0.592 & -0.771 & 0.908 & -0.083 & -0.163 & 0.930 & 1 & & \\
\hline Mg hard & -0.952 & -0.149 & 0.321 & 0.157 & -0.394 & -0.119 & -0.186 & -0.613 & -0.557 & 1 & \\
\hline Cond & 0.698 & 0.833 & 0.469 & 0.464 & -0.201 & 0.814 & -0.466 & 0.504 & 0.190 & -0.667 & 1 \\
\hline
\end{tabular}

Table 5 The correlation matrix between the various physico-chemical properties of water during winter season

\begin{tabular}{|c|c|c|c|c|c|c|c|c|c|c|c|}
\hline Parameters & Temp & $\mathrm{pH}$ & DO & BOD & Free $\mathrm{CO}_{2}$ & $\mathrm{Cl}$ & T.alk & T. Hard & Ca hard & $\mathrm{Mg}$ hard & Cond \\
\hline Temp & 1 & & & & & & & & & & \\
\hline $\mathrm{pH}$ & -0.634 & 1 & & & & & & & & & \\
\hline DO & -0.482 & 0.132 & 1 & & & & & & & & \\
\hline BOD & -0.428 & $0.969 *$ & -0.33 & 1 & & & & & & & \\
\hline Free $\mathrm{CO}_{2}$ & 0.832 & -0.943 & -0.164 & -0.847 & 1 & & & & & & \\
\hline $\mathrm{Cl}$ & 0.464 & 0.285 & -0.792 & 0.498 & 0.082 & 1 & & & & & \\
\hline T. alk & 0.326 & 0.479 & -0.081 & 0.648 & -0.161 & 0.663 & 1 & & & & \\
\hline T. hard & 0.850 & -0.141 & -0.432 & 0.096 & 0.446 & 0.728 & 0.770 & 1 & & & \\
\hline Ca hard & $0.962 *$ & -0.399 & -0.525 & -0.165 & 0.654 & 0.651 & 0.555 & $0.958 *$ & 1 & & \\
\hline $\mathrm{Mg}$ hard & 0.200 & 0.581 & -0.006 & 0.726 & -0.277 & 0.614 & $0.991 * *$ & 0.680 & 0.442 & 1 & \\
\hline Cond & 0.925 & -0.295 & -0.560 & -0.053 & 0.562 & 0.728 & 0.625 & $0.977 *$ & $0.993 * *$ & 0.519 & 1 \\
\hline
\end{tabular}

Table 6 The concentration of heavy metal elements from the 4 sampling stations

\begin{tabular}{llllllll}
\hline SL. no & $\begin{array}{l}\text { Trace } \\
\text { elements } \\
(\mathrm{mg} / \mathrm{l})\end{array}$ & S1 & S 2 & S3 & S 4 & $\begin{array}{l}\text { WHO } \\
\text { permissible } \\
\text { limit* }\end{array}$ & $\begin{array}{l}\text { ISI per- } \\
\text { missible } \\
\text { limit** }\end{array}$ \\
\hline 1 & $\mathrm{Cu}$ & 0.003 & BDL & 0.001 & BDL & 1.0 & 0.05 \\
2 & $\mathrm{Zn}$ & 0.06 & 0.70 & 0.03 & 0.026 & 5.0 & 5.0 \\
3 & $\mathrm{Cd}$ & 0.02 & 0.02 & 0.02 & 0.02 & 0.005 & 0.01 \\
4 & $\mathrm{Mn}$ & 0.014 & 0.013 & 0.036 & 0.011 & 0.14 & $0.1-0.3$ \\
5 & $\mathrm{Se}$ & 0.009 & 0.012 & 0.013 & 0.013 & 0.01 & - \\
6 & $\mathrm{Hg}$ & 0.002 & 0.002 & 0.001 & 0.002 & 0.010 & 0.001 \\
7 & $\mathrm{Fe}$ & 0.17 & 0.02 & 2.0 & 0.65 & 0.3 & 0.3 \\
8 & $\mathrm{As}$ & $\mathrm{BDL}$ & $\mathrm{BDL}$ & $\mathrm{BDL}$ & $\mathrm{BDL}$ & 0.05 & 0.05 \\
9 & $\mathrm{~Pb}$ & $\mathrm{BDL}$ & $\mathrm{BDL}$ & $\mathrm{BDL}$ & $\mathrm{BDL}$ & 0.05 & 0.10 \\
\hline
\end{tabular}

BDL: below detection limit

* Represents WHO: 2008 permissible limit for drinking water (mg/l)

** Represents IS:10,500, 2012 permissible limit for drinking water (mg/l) 
$0.002 \mathrm{mg} / \mathrm{l}$ ). Satarug et al. (2003) show a broad review of the possible sources of $\mathrm{Cd}$ globally. The sources of $\mathrm{Cd}$ at $\mathrm{S} 1$ and S4 may be due to disposal of various electronic wastes along with solid waste without any proper segregation and treatment from the nearby residential zones of the village, institutional quarters and hostels. Presence of Cd at S2 may be due to corrosion of galvanized iron pipes used for carrying water and at $\mathrm{S} 4$ could be associated with the possibility of rock-water interaction in deep aquifers along with runoff from the institutional residential quarters and hostels.

\section{Copper}

Even though $\mathrm{Cu}$ is an essential element in human metabolism, intake of excessively large doses leads to severe mucosal irritation and corrosion wide spread capillary damage, hepatic and renal damage and central nervous system irritation followed by depression. The concentration of $\mathrm{Cu}$ was found in only two stations, i.e., S1 and S3 with values $0.003 \mathrm{mg} / \mathrm{l}$ and $0.001 \mathrm{mg} / \mathrm{l}$, respectively. However, S2 and $\mathrm{S} 3$ were below detection limit (BDL) as shown in Table 6. Concentration of the $\mathrm{Cu}$ is very less compared to the value obtained by Jamir et al (2011) in five district of Nagaland (Wokha: 0.03 to $0.27 \mathrm{mg} / \mathrm{l}$; Tuensang: 0.02 to $0.26 \mathrm{mg} / \mathrm{l}$; Lumami, Zunheboto: 0.04 to $0.08 \mathrm{mg} / \mathrm{l}$; Tseminyu, Kohima: 0.02 to $0.26 \mathrm{mg} / \mathrm{l}$; Ungma, Mokokchung: 0.02 to $0.06 \mathrm{mg} / \mathrm{l}$ ). Hence, the concentration of the copper in all the sampling station is less than the permissible limit given by WHO and ISI. Rozan et al. (1999) showed that geochemical factors can affect the $\mathrm{Cu}$ concentration. Therefore, the possible cause of the increase and pollutant factors of soil, sediments and biota need to be analyzed to determine the accurate reason of the $\mathrm{Cu}$ pollution in the studied sites.

\section{Iron}

Iron is a naturally occurring metal in nature in the form of magnetite, hematite, etc., and enters into water in the extraction of metal from its ore. It also enters into the water when aluminum waste products containing iron are discharged into water. The concentration of $\mathrm{Fe}(\mathrm{mg} / \mathrm{l})$ in the four sampling stations followed the trends as S3 (2.0) $>$ S4 $(0.65)>\mathrm{S} 1(0.17)>\mathrm{S} 2(0.02)$ as shown in Table 6. From our study it was observed that the concentration of Fe at S3 and $\mathrm{S} 4$ is beyond the permissible limit given by WHO and ISI $(0.3 \mathrm{mg} / \mathrm{l})$. However, $\mathrm{S} 1$ and $\mathrm{S} 2$ are below the permissible limit of WHO and ISI. Overall, our results for iron are very high compared with the work of Jamir et al (2011) in Lumami wherein the values ranged from 0.02 to $0.18 \mathrm{mg} / \mathrm{l}$. According to Singh (2004), the amount of iron is relatively high and almost all the states in northeast region contain iron above the permissible level in drinking water. The excess concentration of iron at S3 and S4 may be attributed to rocks and soil containing iron, old pipe of water supply system which can dissolve into the water source. Even though iron poses no danger to health at levels found in drinking water, it may affect acceptability of drinking water by altering its appearance, taste, odor, stain clothing and appliances and promote the growth of iron bacteria in the water system (WHO 2000).

\section{Lead}

Lead is a naturally occurring toxic metal used in many domestic products and enters into water through the corrosion of pipes. In our present study, none of the water samples found detected the presence of $\mathrm{Pb}$ in the sampling stations.

\section{Manganese}

Manganese is an essential trace element abundantly present in earth crust in the form of oxides and hydroxides. Manganese commonly finds its way into water through activities such as industrial emissions, soil erosion, volcanic emissions and the burning human activities. Manganese solids may form deposits within pipes and break off as black particles giving water an unpleasant taste and appearance. It increases the growth of unwanted bacteria that form a slimy coating in water pipes and reservoir (Lemly 2002). The concentration of $\mathrm{Mn}(\mathrm{mg} / \mathrm{l})$ in the four sampling stations followed the trends as S3 (0.036) > S1 (0.014) > S2 (0.013)> S4 (0.011) as given in Table 6 . Values were found to be lower compared to the report by Jamir et al (2011) at Lumami (0.12 to $0.21 \mathrm{mg} / \mathrm{l}$ ) in Nagaland.

\section{Mercury}

In the present study none of the sample were found to exceed the WHO and ISI standard though the concentrations at $0.001 \mathrm{mg} / 1 \mathrm{~S} 1, \mathrm{~S} 2$ and $\mathrm{S} 4$ lie to the maximum permissible limit given by ISI $(0.001 \mathrm{mg} / \mathrm{l})$. The concentrations of $\mathrm{Hg}$ in three sampling stations, viz., S1, S2 and S4, recorded the value of $0.002 \mathrm{mg} / \mathrm{l}$ which is beyond the permissible limit of ISI $(0.001 \mathrm{mg} / \mathrm{l})$ as seen in Table 6. Compared with our results the values of $\mathrm{Hg}$ in water samples of the 4 station were below the permissible limit of WHO (2008). Maximum concentration of $\mathrm{Hg}$ in $\mathrm{S} 1$ (stream water), S2 (tap water) and S4 (spring water) may be attributed due to natural deposits as the area around the University campus has no evident of mining activities.

\section{Selenium}

Selenium in drinking water can come from discharge from mines, refineries, natural deposits or from agricultural runoff leaching natural selenium compounds from dry, 
undeveloped land. Prolonged exposure to selenium above the maximum contaminant level can cause fingernail or hair loss, numbness in extreme cases and circulation problems. EPA (Environment Protection Agency) has set the selenium standard for drinking water at $0.05 \mathrm{mg} / \mathrm{l}$ to protect consumers served by public water systems from the effects of longterm, chronic exposure to selenium. The concentration of $\mathrm{Se}(\mathrm{mg} / \mathrm{l})$ in the four sampling stations followed the trends as $\mathrm{S} 3$ and $\mathrm{S} 4(0.013)>\mathrm{S} 2(0.012)>\mathrm{S} 1(0.009)$ as given in Table 6. The values of Se concentrations in all the four station lie within the permissible limit given by WHO and ISI $(0.01 \mathrm{mg} / \mathrm{l})$. The levels of selenium in groundwater and surface water range from $0.06 \mu \mathrm{g} / \mathrm{l}$ to about $400 \mu \mathrm{g} / \mathrm{l}$ (Scott et al. 1961; Lindberg 1968). In some areas, selenium levels in groundwater may approach $6000 \mu \mathrm{g} / \mathrm{l}$ (Cannon 1964). Concentrations increase at high and low $\mathrm{pH}$ as a result of conversion into compounds of greater solubility in water. Levels of selenium in tap water samples from public water supplies around the world are usually much less than $10 \mu \mathrm{g} / \mathrm{l}$ but may exceed 50 g/l (NAS 1976, 1977; Gore et al 2010).

\section{Zinc}

Zinc leaks from zinc pipes and rain pipes, consequential to circulation of carbon-rich water. Increase concentration of zinc may cause toxicity leading to stomach aches, vomiting, colics, fevers and diarrhea (Wang et al. 1991). In our present study none of the samples exceed WHO, ISI and BIS standards. The concentration of $\mathrm{Zn}(\mathrm{mg} / \mathrm{l})$ in all the sampling stations followed the trend as $\mathrm{S} 2(0.7)>\mathrm{S} 4$ $(0.026)>\mathrm{S} 3(0.03)>\mathrm{S} 1(0.06)$ as given in Table 6. Value of $\mathrm{Zn}$ at $\mathrm{S} 2$ is comparatively similar with the work of Jamir et al (2011) in Lumami, Zunheboto district of Nagaland where they obtained the concentration of $\mathrm{Zn}$ ranges from 0.45 to $0.78 \mathrm{mg} / \mathrm{l}$. Higher concentration of $\mathrm{Zn}$ from $\mathrm{S} 2$ may be attributed due to dissolution of $\mathrm{Zn}$ from water pipelines.

\section{Conclusion}

The results of the physico-chemical parameters of the water show that value of $\mathrm{DO}, \mathrm{BOD}_{5}$ and free $\mathrm{CO}_{2}$ at $\mathrm{S} 3$ is beyond the permissible limit set by WHO and BIS. The values of DO in all the three stations (S1, S2 and S4) are near to the maximum permissible limit of drinking water, indicating the deterioration of water quality, whereas the rests of the parameters are below the permissible limit of WHO and BIS.

Correlation studies between the variables of the physico-chemical parameters indicate that during rainy season, DO was found to be highly significant with chlorine, free $\mathrm{CO}_{2}$, with total alkalinity, Ca hardness and conductivity, total alkalinity with $\mathrm{Ca}$ hardness and total hardness with $\mathrm{Mg}$ hardness. In summer, $\mathrm{pH}$ was found to be highly significant with $\mathrm{Cl}, \mathrm{BOD}$, with free $\mathrm{CO}_{2}$. In winter, temperature was found to be highly significant $\mathrm{Ca}$ hardness, total alkalinity with $\mathrm{Mg}$ hardness and total hardness with $\mathrm{Ca}$ hardness. These relationships show that $\mathrm{DO}$ and free $\mathrm{CO}_{2}$ are the most important parameters of water quality parameters which indicate the pollution status of water quality. The results of the concentrations of some heavy metals such as $\mathrm{Cu}, \mathrm{Zn}$ and $\mathrm{Mn}$ in all the 4 sampling stations are below the maximum permissible limit prescribed by WHO and ISI. The concentration of $\mathrm{Cu}$ is below the detection limit at $\mathrm{S} 2$ (tap water) and $\mathrm{S} 4$ (spring water), whereas the concentration of $\mathrm{As}$ and $\mathrm{Pb}$ was not detected in all the 4 stations. The concentrations of $\mathrm{Hg}$ were detected in all 4 stations, and the values were higher than the maximum permissible limits ISI $(0.001 \mathrm{mg} / \mathrm{l})$ but lower than WHO limit, i.e., $0.010 \mathrm{mg} / \mathrm{l}$. Hg level was similar in all the 4 stations. The concentrations of $\mathrm{Fe}$ were beyond the maximum permissible limit at S3 (well water) and S4 (spring water), whereas at S1 (stream water) and S2 (tap water) the values were below the permissible limit prescribed by WHO and ISI, i.e., $0.3 \mathrm{mg} / \mathrm{l}$.

From the study, we can conclude our hypothesis that except well water rest of the water sources, namely spring, stream and tap water, are not much polluted and fit for domestic uses. However, the detection of $\mathrm{Hg}$ and $\mathrm{Fe}$ in all the four types of water sources is an indication of contaminant hazards which, in turn, have implications on the human health.

This study, therefore, recommends the government and other responsible authorities of the area to: (1) introduce relevant drinking water treatment techniques which can mitigate the current levels of heavy metals, (2) prevent any kind of waste disposal into streams, or any reservoirs that supply domestic drinking water, (3) educate the people to have better drinking water storage practices, (4) support for further study to investigate into biological parameters of significant health concern and (5) lastly, soil and crops cultivated in the vicinity of the areas need to be evaluated for the detection of PTEs.

Acknowledgement Authors are grateful to Scientist at CSIR-North East Institute of Sciences and Technology, Jorhat, India, for assisting in the analysis of water samples for trace heavy metal elements using AAS (AAnalyst 600, Perkin Elmer Inc., MA, USA).

Authors' contributions The first author is a M.Sc student; the manuscript is based on his M.Sc dissertation work. The second and third authors are the guides of the first author under whose supervision the research is carried out.

Funding Not applicable.

\section{Declaration}

مدينة الملك عبدالعزيز

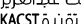
KACST للعلوم والتقنية 
Conflicts of interest The authors declare that they have no conflict of interest.

Consent for publication The authors agree to publish the paper based on the research conducted.

Availability of data and material The data collected are a part of the M.Sc dissertation work and are provided with the best of its experiments.

Consent to participate All the authors agreed to partake on the research conducted.

Open Access This article is licensed under a Creative Commons Attribution 4.0 International License, which permits use, sharing, adaptation, distribution and reproduction in any medium or format, as long as you give appropriate credit to the original author(s) and the source, provide a link to the Creative Commons licence, and indicate if changes were made. The images or other third party material in this article are included in the article's Creative Commons licence, unless indicated otherwise in a credit line to the material. If material is not included in the article's Creative Commons licence and your intended use is not permitted by statutory regulation or exceeds the permitted use, you will need to obtain permission directly from the copyright holder. To view a copy of this licence, visit http://creativecommons.org/licenses/by/4.0/.

\section{References}

Antoniadis V, Golia EE, Shaheen SM, Rinklebe J (2017) Bioavailability and health risk assessment of potentially toxic elements in Thriasio plain, near Athens, Greece. Environ Geochem Health 39:319-330

APHA (2005) Standards methods for the examination of water and waste water, 21 st edn. American Publication Health Association, Inc Washington, D.C.

Azrina A, Khoo HE, Idris MA, Amin I, Razman MR (2011) Major inorganic elements in tap water samples in Peninsular Malaysia. Malays J Nutr 17(2):271-276

BIS (IS: 10500-1991) Drinking water Specification. New Delhi, India

Cannon HG (1964) Geochemistry of rocks and related soils and vegetation in the Yellow Cat area, Grand County, Utah. Washington, DC, United States Geological Survey (Bulletin No. 1176)

Department of the Environment, Welsh Office (DEWO) (1989) Guidance and safeguarding the quality of public water suppliers. Her Majesty's Stationery Office London

Girija TR, Mahanta C, Chandramouli V (2017) Water Quality Assessment of an Untreated Effluent Impacted Urban Stream: The Bharalu tributary of the Brahmaputra River, India. Env Mon \& Ass 130:221-236

Gore F, Fawell J, Bartram J (2010) Too much or too little? A review of the conundrum of Selenium. J Water Health 8(3):405-416

Husssain S (1987) Water Supply and Sanitary Engineering. Oxford and IBH Publishing Co.Pvt, Ltd, New Delhi

IS 10500 (2012) Drinking Water Specification. 2nd Revision. Publication Unit, BIS, New Delhi, India

Jamir TT, Bembee WD, Ibotomba US, Bhubon SRK (2011) Lead, iron and manganese contamination in spring, pond and well water in Nagaland, one of the Seven North-Eastern states of India: a future danger. J Chem Pharm Res 3(3):403-411

Jonnalagadda SB, Mhere G (2001) Water quality of the Odzi River in the eastern highlands of Zimbabwe. Water Res 35(10):2371-2376

Khan SA, Khan H, Ishtiaq M, Saddique U, Muhammad S, Farooq M (2018) Shallow water proved higher levels of potentially harmful elements and human health risk along the Sadkal oil exploration and production. Desalin Water Trea.t https://doi.org/https://doi. org/10.5004/dwt.2018. 22385

Kibami D, Pongener C, Rao CK, Sinha D (2014) Linear correlation study and regression analysis of drinking water quality in Mokokchung town, Nagaland, India. Int J Engg Res \& Management 1(3):2349-2058

Kumar V, Majagi S, Jadesh M, Kumar VB (2005) Pollution studies of Bhera river at Gulbarga. Eco Env and Cons 11(3-4):467-469

Lemly AD (2002) Selenium assessment in aquatic ecosystem- a guide for hazard evaluation and water quality criteria: New York, Springer-Verlag, $3 \mathrm{p}$

Lindberg P (1968) Selenium determination in plant and animal material and in water. A methodological study. Acta Veterinaria Scandinavica, Suppl 23:1-48

Moshood KM (2008) Assessment of water quality of Oyun Reservoir, Offa, Nigeria, using selected physico-chemical parameters. Turkish J of Fisheries and Aquatic Sci 8:309-319

NAS (1976) Selenium. DC, National Academy of Sciences, Washington

NAS (1977) Drinking water and health. DC, National Academy of Sciences, Washington

Nollet LML (2000) Handbook of Water Analysis. Marcel Dekker, New York, NY, USA

Raney ED, Menzel BW (1969) Ichthyological associates. Bull Ithaca B.Y.2

Rozan TF, Benoit G (1999) Geochemical factors controlling free $\mathrm{Cu}$ ion concentration in river water. Geochemica et Cosmochimica Acta 63:3311-3319

Saddique U, Muhammad S, Tariq M, Zhang H, Arif M, Jadoon IA, Khattak NU (2018) Potentially toxic elements in soil of the Khyber Pakhtunkhwa province and tribal areas, Pakistan: evaluation for human and ecological risk assessment. Environ Geochem Health $1-14$

Satarung S, Baker JR, Urbenjapol S, Haswell-Elkins M, Reilly PE, Williams DJ, Moore MR (2003) A global perspective on Cadmium pollution and toxicity in non-occupationally exposed pollution. Toxico Lett 137(1-2):65-83

Saxena MM (1987) Environmental Analysis-Water. Agro Botanical Publisher (India), Soil and Air

Scott RC, Voegeli PT Jr (1961) Radiochemical analysis of ground and surface water in Colorado. Colorado Water Conservation Board (Basic Data Report 7)

Shah M, Ara J, Muhammad S, Khan S, Tariq S (2012) Health risk assessment via surface water and sub-surface water consumption in the mafic and ultramafic terrain, Mohmand agency, northern Pakistan. J Geochem Explor 118:60-67

Shakoor MB, Nawaz R, Hussain F, Raza M, Ali S, Rizwan M, Eun-Oh S, Ahmad S (2017) Human health implications, risk assessment and remediation of as-contaminated water: a critical review. Sci Total Environ 601-602:756-769. https://doi.org/10.1016/j.scito tenv.2017.05.223

Singh AK (2004) Arsenic contamination in groundwater of NorthEastern India. Proceedings of national seminar on hydrology with the focal theme on "Water Quality" held at National Institute of Hydrology, Roorkee

Tripathee L, Kang S, Sharma CM, Rupakheti D, Paudyal R, Huang J, Sillanpää M (2016) Preliminary health risk assessment of potentially toxic metals in surface water of the Himalayan rivers. Nepal Bull Environ Contam Toxicol 97:855-862

Trivedy RK, Goel PK (1984) Chemical and Biological methods for water pollution studies. Environmental Publication Karad, India, pp: 122

Ullah Z, Naz A, Saddique U, Khan A, Shah W, Muhammad S (2017) Potentially toxic elements concentrations and human health risk 
assessment of food crops in Bajaur agency. Pakistan Environ Earth Sci 76:482

WHO (1983) International Standards for drinking water. World Health Organization, Geneva p, pp 1-7

WHO (2000) Disinfectants and disinfectant by products. Environmental Health Criteria 216, Geneva: World Health Organization

WHO (2004) Guidelines for Drinking-water Quality. World Health Organization, Geneva
WHO (2006) In Water, Sanitation and Health World Health Organization

WHO (2008) Guidelines for Drinking-water Quality. WHO Press, Geneva, Switzerland 3rd edition incorporating the 1st and 2nd Addenda. Vol 1 Recommendation 